\title{
The guild and the swordsman
}

\author{
Jean Chandler
}

with translations by Jack Gassman and Christian Trosclair, edited by Willy Rosencrans, and special thanks to Willy Rosencrans, Marjorie Dalton, Olivier Dupuis, Christian Trosclair, Jürg Gassmann, Kel Rekuta, Ariella Elema and Jake Norwood.

Abstract - Guilds have a well-established association with the fencing systems of medieval Europe, and the phenomenon of guilds has been the subject of a great deal of new academic research in the last 20 years or so. A thorough summary of the recent scholarship on guilds and their structure and history will help provide context for what may be loosely described as armed guilds. Though armed guilds have not yet been the subject of a proper systematic analysis, it is possible to tentatively identify four types. Combining the summary of 'civilian' guilds with the emerging evidence of armed guilds, including the fencing guilds, may help us better understand the social relevance of martial arts in medieval and Early Modern Europe. This may in turn contribute positively to the ongoing efforts to interpret the medieval fightbooks.

Keywords - guilds, armed guilds, societates armatae, fencing guilds

\section{INTRODUCTION}

This paper has two purposes.

The first is to summarize the recent scholarly work on guilds, in order to help provide an accurate context for fencers and researchers in the historical fencing community who may be interested in the links between fightbooks, fencing masters and guilds. A great deal of work has been done in the academic community on the subject of guilds in the last couple of decades which changes the perception of them to no small degree. I will review some of this work and outline the current theories on the origins, spread, and structure of guilds in Europe. This extends from the original proto-guilds and insurance associations to merchant guilds, craft guilds, and journeymen societies.

The second purpose is to sketch out a rough outline of what I call "armed guilds" and propose a very provisional placement of them within the established model of guilds. I will note where there appear to be links between the armed guilds and the social and economic types, and the relationships which we can begin to detect between the distinct types of armed guilds themselves.

The armed guilds do not seem to have yet been systematically defined in academia, and it is far too early to propose firm theories about precisely where they fit into the existing models of guilds and their development. The research is only in the preliminary phases. But we do have sufficient data to tentatively identity four types: the constaffler society, the societates armatae, the shooting guild, and the fencing guild. 
By going through the latest data on guilds before I touch upon the limited data currently available on "armed" guilds, I am hoping to help other researchers better understand where they may be able to fit the two types together. Elements of merchant and craft guild structures may, or may not, relate to the organization of armed guilds in a variety of ways, but it is helpful to understand the former in order to find a proper context for the latter.

Although guilds played a huge role in the civilization of late medieval Europe, they remain poorly understood in the English-speaking world outside of academia. For most of the $19^{\text {th }}$ and $20^{\text {th }}$ centuries, mainstream academics virtually ignored guilds. The most influential economic, political, and philosophical thinkers from such opposite wings of the political spectrum as Adam Smith (in his Wealth of Nations) ${ }^{1}$ to Karl Marx (in The Communist Manifesto $)^{2}$ were oddly in agreement in their dislike of guilds.

In the last thirty years, however, and especially during the last fifteen (roughly the same period that the HEMA revival has taken place), there has been an extraordinary resurgence of scholarly interest in the subject. Much of this is of relevance to historical fencers because it provides valuable context which can help connect the dots between fight-books, known fencing masters, and the fencing guilds in a few specific ways. Historical fencers are, conversely, relevant to academics currently studying guilds because of their insight as a community into the paramilitary and armed guilds of central and northern Europe - which have not been yet substantially included in the corpus of recent literature on guilds ${ }^{3}$.

Some of the new research on guilds has proposed an emerging body of theory that craft guilds played a crucial and largely positive role in European history in four ways. Guilds were crucial in the process of urbanization and closely linked to the development of towns in Europe; they contributed to the remarkable mobility of labor in the medieval world (Epstein, 2008:16); they enhanced the spread of technology and special skills (Epstein, 2008:18); and they contributed to the development of an armed urban citizenry with permanent militias (Eltis, 1989:7-10) (Verbruggen, 1954:152,171,174). These militias were largely based upon the establishment of special paramilitary and martial guilds as described by Dr. Gassman elsewhere in this issue.

\footnotetext{
1 Adam Smith on Guilds "People of the same trade seldom meet together, even for merriment and diversion, but the conversation ends in a conspiracy against the public, or in some contrivance to raise prices." - Adam Smith, The Wealth of Nations: An Inquiry into the Nature \& Causes of the Wealth of Nations (Book I, Chapter X, paragraph 72):

2 Karl Marx on Guilds: Communist Manifesto, Chapter 1, page 1: "Freeman and slave, patrician and plebeian, lord and serf, guild-master ${ }^{(3)}$ and journeyman, in a word, oppressor and oppressed" 3 Professor Tlusty makes brief mention of the fencing guilds in her Martial Ethic in Early Modern Germany but does little more than repeat the basics.
} 
It is something of a mystery as to when precisely the disreputable and marginal "hired gun" fencer of early-medieval judicial combat changed in status to the somewhat respectable fencer practicing his art in the late medieval period, sanctioned and hired by town authorities and princes. The history of the guilds takes an interesting turn in this same period which could be related, and may have set the groundwork for state-sanctioned royal schools of fencing which appeared in the early modern era. In the medieval era the journeymen societies appear to be unique to central Europe (though they developed in other parts of the world in the $17^{\text {th }}$ and $18^{\text {th }}$ centuries). This also may have some importance due to the close association between journeymen and the militias, the armed societies, and activities such as the sword dance (Tlusty:2011,217).

\section{PART ONE: THE RECENT SCHOLARSHIP ON GUILDS}

For most of the twentieth century, scholars in the English-speaking world especially have shown comparatively little interest in guilds. Beginning the 1980's (Epstein, 2008:2), a few academics began to publish papers which did not quite fit the old paradigm of the guild as an impediment to the development of European society. It was not until the late 1990s that a really new analysis of old European records proposed a revisionist approach (Lucassen:2009:7). The chief proponent of this trend, Dr. Stephen R. Epstein, a professor from the London School of Economics, published a series of articles attacking the traditional view that guilds were impediments to technological progress, rent-seeking (meaning they damaged the economy by increasing their own wealth without creating wealth in turn) and elitist.

The most notable champion of the latter position was and still is Sheilagh Ogilvie of the University of Cambridge, also in the UK. Professor Ogilvie published a very in-depth study of rural guilds in Württemberg in southern Germany in the 17th and 18th centuries (Ogilvie, 1997). The guilds in Ogilvie's study were involved in the production of worsted, a type of yarn, in a poor rural area in the Black Forest. They seem to have fit the pattern of the repressive, regressive guild very well, and Ogilvie extrapolated this to all the European guilds from the medieval period onward.

Epstein pointed out that Ogilvie's study was limited because it focused on a rural guild in a secondary industry, and at a rather late stage in the history of guilds. Rather than contradict her evidence, he basically added nuance to the earlier pejorative arguments, portraying guilds as sometimes "good", sometimes "bad", and always an extremely complex phenomenon. Very generally, however, Epstein demonstrated that guilds were a much more energetic and dynamic force in the European economy than previously thought and, as often as not, pushed it forward rather than backward. 
In what amounted to the first modern synthesis of the role of guilds in Europe, in an article published in 1998, Epstein argued that rather than blocking technology, guilds typically steered it in a skill-intensive direction, and were often early adopters of technical innovation (Epstein, 2008:18). Rather than blocking social mobility, they enabled a very effective system of training which brought people from the countryside (sometimes from very far away) into the city and into skilled labor. The "rent-seeking" behavior so often attributed to guilds was more limited to low skill industries with strong political connections, but the most successful early guilds actually thrived in the least politically coherent polities. In a more general sense, Epstein said that rather than rent-seeking, guilds were cost-sharing enterprises (Epstein, 2008:47).

In the increasingly heated debate, Ogilvie suggested that the reason England and Holland thrived in the modern era compared to continental Europe was that those nations were relatively free of guilds. Epstein and his colleagues Maarten Prak and others responded with a detailed study of guilds in Holland. Guilds thrived in the Netherlands in the boom times of the 17th century, dominating most of the key industries, and more guilds were formed at this time in Holland than at any other (Epstein, 2008:21). For example Prak and his colleagues pointed out that the famous Dutch painting masters Rembrandt et al. were in an industry heavily regulated and dominated by guilds (Lucassen, 2009:78-79). Prak in fact suggested that the painters' guilds, which had originated in Flanders but moved north after the Spanish occupation, were largely responsible for raising the culture of painting in the Low Countries and establishing and spreading the market for it into the middle classes.

Epstein's work found considerable support, particularly in Holland and Italy, and since there was so much data in the form of old records ready for analysis, it led to major academic conferences (Lucassen,2009:5) and a flurry of papers being published. A good summary of the new data and analysis was laid out in the groundbreaking Guilds, Innovation, and the European Economy, $1400-1800$ by S.R. Epstein and Maarten Prak, published in 2008, shortly after Epstein's death in 2007. 


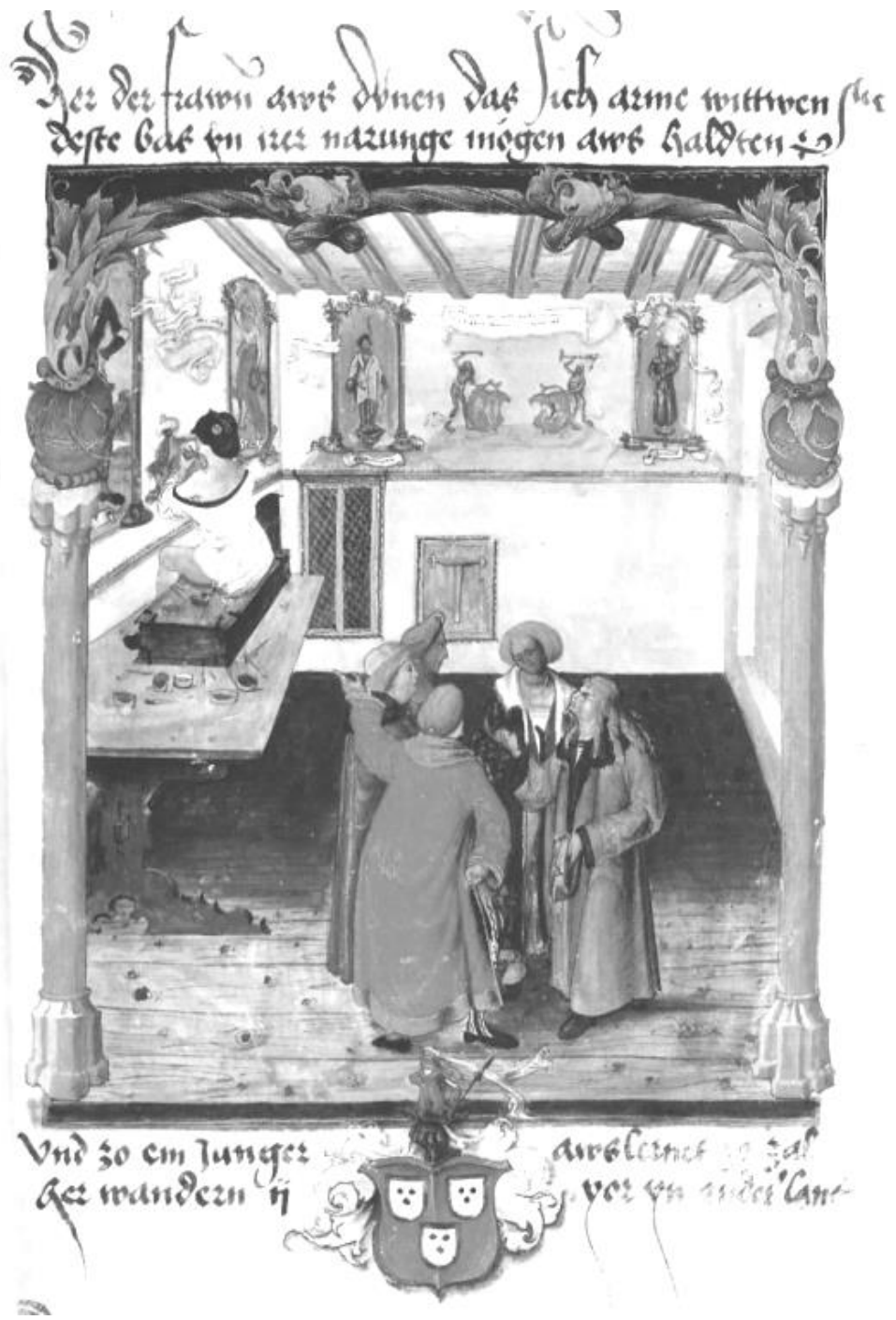

Painters' atelier, Balthasar Behem Codex, Krakow, 1505

His supporters in academia further advanced the revisionist case in The Return of the Guilds, edited by Jan Lucassen, Tine De Moor, and Jan Luiten van Zanden (2009). Expanding further upon this work they showed that European-style merchant and craft guilds also existed well beyond Europe - for example in the Ottoman Empire from the early $16^{\text {th }}$ century onward and in China and Japan in the $19^{\text {th }}$ century. They also presented a great deal of data supporting Epstein's earlier conclusions about the European guilds in Italy, the German-speaking territories, France, and the Low Countries where several detailed studies were conducted. Several articles examined 
some later (and therefore even better-documented) examples of the phenomenon in France, Holland, and the Venetian Republic in the $17^{\text {th }}$ and $18^{\text {th }}$ centuries.

Since Epstein's death Ogilvie has continued to pursue her side of the argument as well. She published a major new book supporting her previous positions in 2011. This was an analysis of merchant guilds rather than craft guilds, however, and she based her argument partly on equating merchant guilds with mercantile trading companies such as the East India Company, which is a bit of an outlier position. Meanwhile some from Epstein's camp have gone so far as to suggest that craft guilds in particular may have been a major factor in the so-called European "Little Divergence" and "Great Divergence," when European economies and technologies pulled so far ahead of the rest of Eurasia (Lucassen, 2009:9). Without a doubt the debate will continue to evolve, and it is far too early to draw definitive conclusions, but both sides, particularly from Epstein's camp, have brought to light a lot of interesting data to consider.

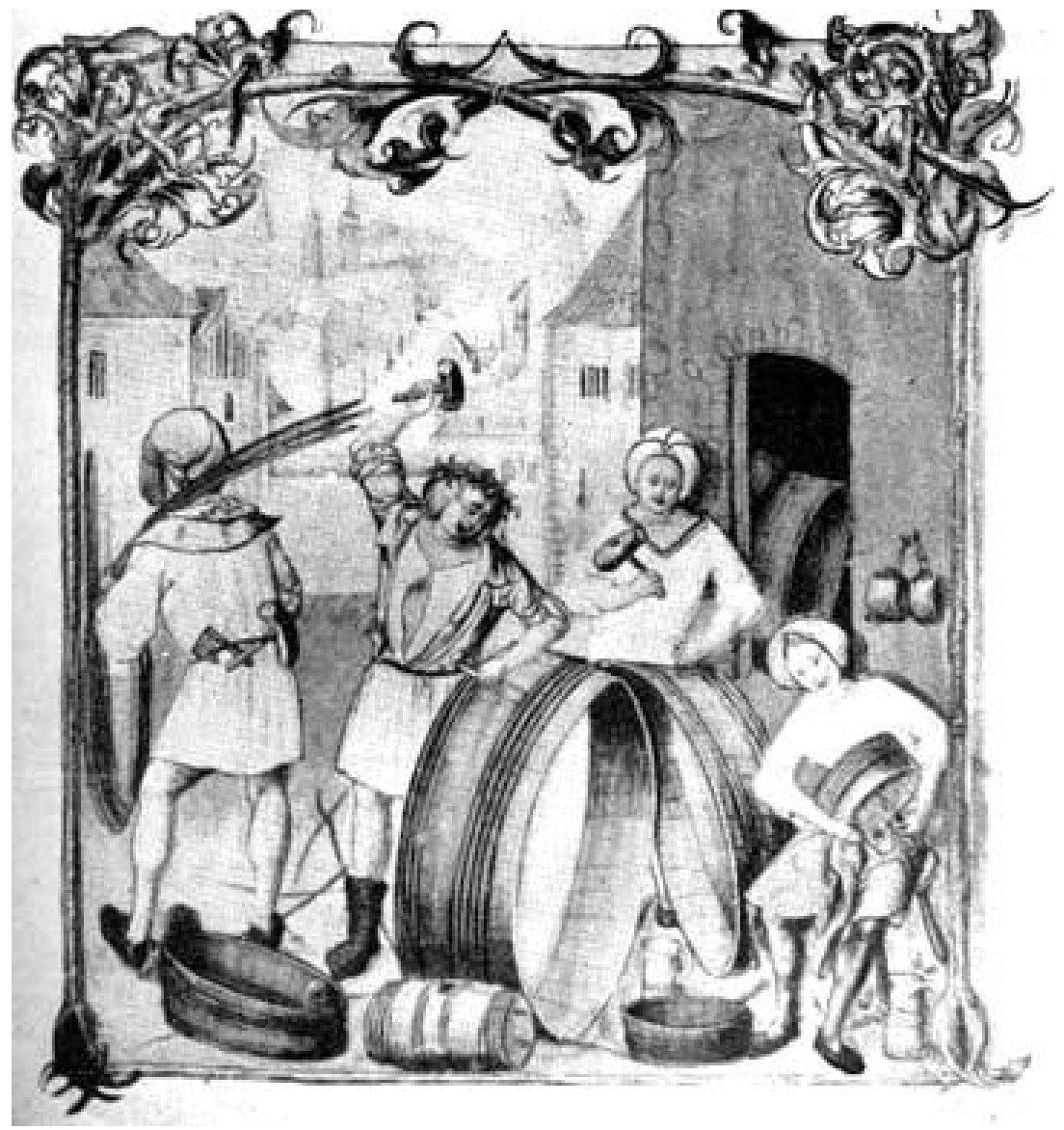

Barrel-makers' guild workshop, Balthasar Behem Codex, 1505, Krakow 


\section{Guilds and technology}

One of the consistent criticisms of guilds is that they held back technological change and therefore social and economic progress, out of selfish protection of their old jobs. But the revisionists showed many cases where this was not the pattern. For example, Francesca Trivellato of Yale conducted a very detailed study of craft guilds in Venice in the glass and silk industries (Lucassen, 2009). Both industries, arguably the two most important in Venice, were dominated by craft guilds from the medieval period through the $18^{\text {th }}$ century.

The survey showed remarkable agility from glass and silk makers in adapting to the tumultuous economic changes of that period (Epstein, 2008: 210). Far from suppressing or resisting technology, they often actively embraced it and used new machines, raw materials, and techniques both of local and foreign origin to adapt to changing economic and political circumstances. Interestingly, Venice was one of the first places to grant patents, starting in the $15^{\text {th }}$ century (Epstein, 2008:222), and Trivellato was able to trace the adaptation of several inventions patented both by Venetians and by foreigners. Ultimately she concluded that by the end of the Venetian Republic, it was more often the merchants who were resisting change while the guilds were seeking it out.

For example, the glass industry was able to shift from producing mirrors, eyeglasses and glassware for middle class consumption in the $15^{\text {th }}$ century to mass production of beads and tiny glass mirrors for the Royal African Company and the Hudson Bay Company in the $16^{\text {th }}$ century (Epstein, 2008:211), then shifting to the Russian luxury market in the $17^{\text {th }}$ before reverting to mass market products again in the 18th. Similarly the silk industry shifted several times between luxury goods such as damask fabric and fine clothing to such prosaic items as silk stockings for working class women in England and cheap brocades made out of waste silk. Eventually they split into two distinct industries, a high-end luxury production complex and a cheaper wholesale enterprise for the mass market (Epstein 2008: 218-211).

This rapid shift in the economic structure of entire industries was possible for two reasons: the constant stream of new inventions, techniques and machines which became available, and the ability of the guilds to quickly reorganize themselves into new networks of contractors and subcontractors (Epstein,2008:228). Rather than fight every change, the guilds simply shifted and reorganized themselves to take advantage of the new realities, and pushed for technologies which emphasized skilled labor where possible. If mass production of silk textiles was becoming less lucrative and more automated, new specialized guilds emerged for making fancy clothing or fabrics. For example, Mexican cochineal dye arrived in Europe in 1540 and became very popular in the textile market. Rather than fight the new trend the Venetian silk industry became experts in the production of fabrics using this dye and were the leading exporters by 1543 . 
Guilds had political power and did sometimes attempt to block certain innovations. Trivellato describes how the Venetian glassmaking guilds managed to block the adaptation of a French technique for making large cast mirrors in the 17th century. The glassblowers' guild thought it would cost jobs and money and managed to get it banned, but making the effort to block technology in this way was difficult and politically risky. Far more often the Venetian guilds eagerly adopted new techniques and devices.

Examples of this type are not limited to the early modern period. Important new technical innovations in construction and textiles and attributed to the crafts have been traced to 1100 (Geis,1994:125). One instance was the production of iron and copper wire. Prior to the medieval period this was done laboriously in the forge with hammer and tongs, but the mail armor-making crafts developed the draw plate, a revolutionary method for making wire by extruding hot iron through a series of ever smaller holes (Geis, 1994:125). This obviously had numerous applications well beyond the production of armor.

The production of soap was revolutionized by craft guilds who started using olive oil instead of animal fat, thus spreading the production of the popular export product from Scandinavia where it had started down into France, Venice, and Catalonia (Geis:1994:177). Nor were such innovations limited to simple craft techniques. New machines for the process of spinning and carding both natural and animal fibers into textiles were introduced by guilds in Flanders in the $13^{\text {th }}$ century (Geis:1994:177). Initially the craft guilds were very cautious about these inventions, as they produced inferior textiles, but they learned how to improve the quality and gradually introduced them for the production, initially, of the weft on the new spinning wheel while the warp, which had to use stronger and longer thread, was spun on the spindle. By the $14^{\text {th }}$ century the new technologies had been much improved and fully integrated into the textile industry, thus increasing production to meet the rising demand (Geis:1994:177).

Another specific example was the dissemination of the metal vice, a general purpose tool useful in metalworking, woodworking, and many other crafts. It was spread during the $16^{\text {th }}$ century from Nuremburg throughout Europe by journeymen and masters of the cutlers' guild (Epstein - (Reinhold Reith) :2008,138). We can also learn from the dissemination of the technology of the printing press. Johannes Gutenberg, the famous originator of this momentous invention, relied on metallurgical skills he learned as a goldsmith to produce the new type of printer's metal which was crucial to the process, in addition to adopting a type of agricultural press and developing a new oil-based ink.

One of his early colleagues, Hans von Speyer, another goldsmith who may or may not have been the same Hans von Speyer who wrote the fencing manual MS M.I.29 which appeared after his death (1491), was the first person to introduce the printing press to Venice. This was a notable irony since Venice was the origin of equally important paper mill to Germany. Gutenberg's secret was out by 1457 , and merchant entrepreneurs 
linked to his initial operation set up the first few presses. But within two years apprentices and journeymen had begun spreading the technology as well, first to Bamburg, then Strasbourg, then Cologne, then Basel, then Augsburg. By 1475 it had spread to Poland (Krakow), Spain (Seville, Barcelona), Italy (Rome, Venice), the Low Countries (Bruges, Amsterdam), and France (Paris, Lyon). By 1500, over 1,000 printing presses had been set up around Europe, producing over 8,000,000 books and pamphlets. The rest, of course, is history.

\section{Three stages in the development of guilds}

Modern researchers have identified three distinct and recognizable stages of guild development in medieval Europe (Lucassen, 2009:14-15), a pattern which was later repeated to a greater or lesser extent beyond Europe in the early modern period. The first saw the development of the merchant guilds. In the second stage, the craft guilds appeared and rose to prominence. Finally the journeymen's associations took shape and began to exert pressure upon both the guilds and the merchants.

According to the Epstein camp, guilds are defined as "...permanent, generally local organizations of people in the same profession or trade or a combination of the same professions, recognized by the local, provincial, or central government, and which have as their main, but certainly not exclusive, purpose the defense and maintenance of trade monopoly rights with regard to fellow citizens and outside competitors." (Lucassen, 2009:6)

The first true guilds in Europe came together in the $9^{\text {th }}$ and $10^{\text {th }}$ centuries, appearing in the Low Countries, northern Germany, and northern Italy, at least so far as we currently know (Lucassen, 2009:14-15). Some guild-like structures, known as collegia, were previously documented in ancient Rome and the Byzantine Empire, but it is doubtful that Roman collegia met the criteria of a guild because they do not appear to have been truly autonomous from Roman authorities, and therefore lacked the same agency as the medieval European guilds, and may have been clan-based. They may, however, have influenced the Lombards and Visigoths who conquered the ancient Roman towns in Southern Europe as tribal kin-groups were forced to adapt to urban life. 


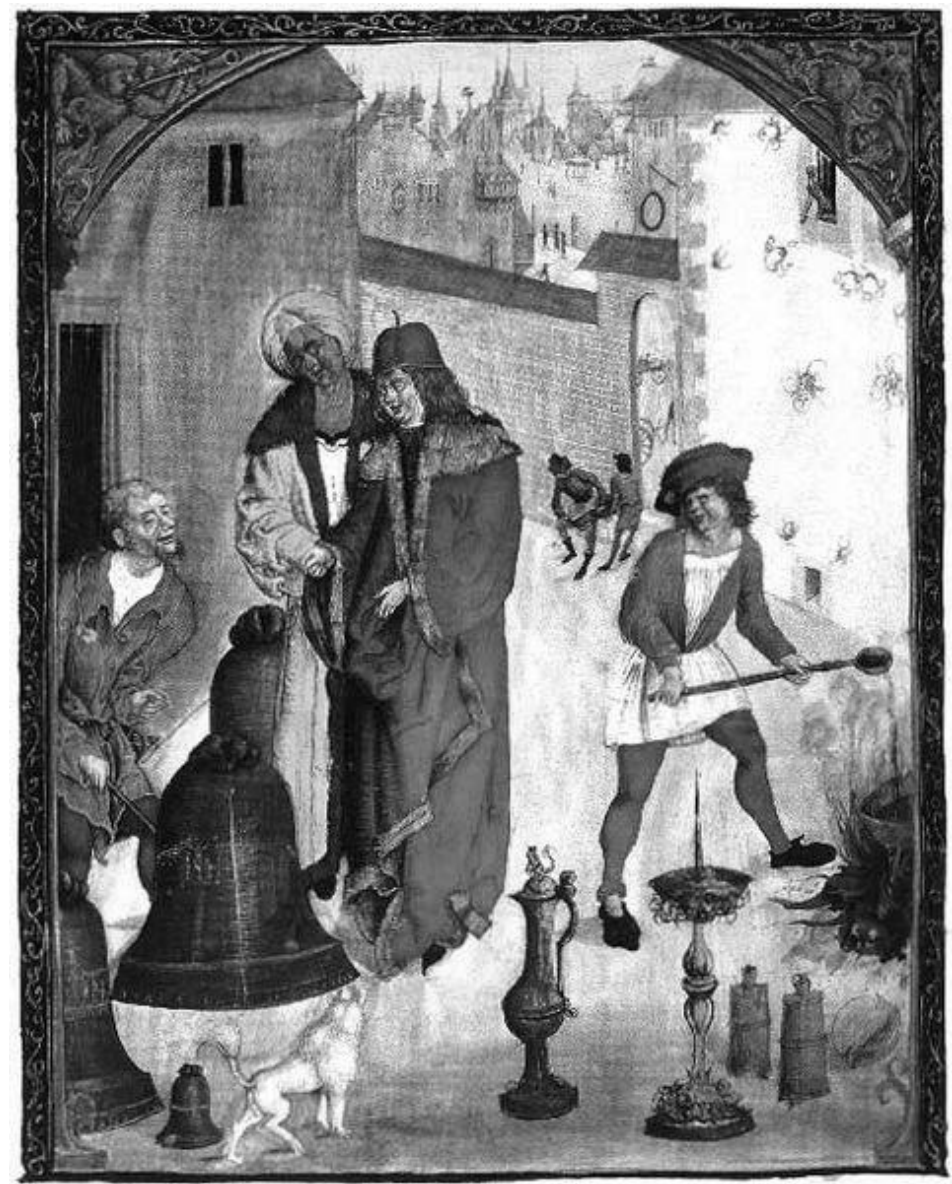

Bellfounders' workshop, Balthasar Behem Codex, Krakow 1505

Whatever the influence of Roman traditions in Italy, the guilds clearly had indigenous precursors among the barbarian tribes of the far north, because they became established early on in Saxony, Flanders, and Swabia (Epstein, 2008:155-174). These medieval European craft guilds introduced organization on the basis of free association rather than tribal or ethnic affiliation (Epstein 2008: 155-174).

The craftsmens' guilds of the second stage appear in the records during the $12^{\text {th }}$ century. The first were in the most energetic towns of northern Italy and the Low Countries, then in France, lower (i.e. northern) Germany and the Rhineland, the Iberian peninsula, and the Slavic-speaking regions of central Europe in the $13^{\text {th }}$ century. In many cases during their rise the craft guilds formed paramilitary societies which became the core of the military forces of the town. The reliance of the town on the craft guild militias was a 
direct reason for their rise to political power in the towns (Eltis, 1989:8). Sometimes this was temporary, sometimes long-lasting.

The third stage of the development of guilds described by Epstein, Prak and Lucassen et al is the development of organizations specifically for journeymen. Western Europe didn't reach this third stage until the $17^{\text {th }}$ and $18^{\text {th }}$ centuries (Lucassen, 2009:14-15), and outside of Europe even later, in the $19^{\text {th }}$ or $20^{\text {th }}$. But in certain of the German and Slavic parts of central Europe - regions which as I pointed out in my paper last year correlate pretty well with the known early fencing manuals and fencing masters (Chandler:2013,108) journeyman's associations appeared much earlier indeed, in the $14^{\text {th }}$ or $15^{\text {th }}$ century (Lucassen, 2009:15). This coincides with the first evidence of shooting clubs, fencing societies, and other martial sports clubs appearing in the records (Tlusty, 2011:187).

This may not mean anything at all, but at the very least it is interesting in context because the rise of the journeyman also corresponded with a substantial increase in the circulation of urban craftsmen between towns, due to the tradition of the walz (traveling years). It is well established that circulating journeymen spread technologies from one town to the next, and from one region to the next - indeed they traveled across the length and breadth of Europe and even beyond Europe. Johannes Janssen quotes Felig Fabri of Ulm in 1484 who noted that German jewelers, goldsmiths, stonecutters, and carriage makers worked for the "Saracens" (Janssen,1896:7) and the Ottoman Sultan hired a German stonemason to build the wall around the Alexandria harbor in Egypt.

We also know that journeymen were allowed to carry swords in most central and northern European towns (Tlusty, 2011:154-155), and were disproportionately represented in both the martial guilds and the militias (Tlusty, 2011:37).

\section{Early guilds and urbanization}

"The commune is an oath of mutual aid (mutui adjutorii conjuratio). A new and detestable word. Through it the serfs (capite sensi) are freed from all serfdom; through it they can only be condemned to a legally determined fine for breaches of the law; through it, they cease to be liable to payments which the serfs always used to pay."

-Guibert of Nogent, 1115 AD (Swinton Bland:1958,111-114)

As the guild replaced the tribe or kin-group in the early medieval urban commune, it was closely associated with urban development in Europe (Lucassen, 2009:14). In the medieval period it seems that the guild as such was unique to Europe (Lucassen, 2009:10). The Arabs, for example, did not develop guilds until they came under Ottoman control in the $16^{\text {th }}$ century, despite early and very highly developed urbanization. The difference between European and Arab polities at that time may have been that the latter had retained more of their tribal structure, or that their political organization was more authoritarian.

Early barbarian societies were social clubs and, essentially, insurance associations. Trade was a risky business in this period: the term guild derives from "geld," for the gold 
stored in the guilds' chests to be distributed to widows and orphans of their members in the event of a catastrophe. They swore fearsome oaths of mutual defense and support, forming a new type of urban tribe, the innung, cech, zünfte or brüderschaft. This new custom worried the Church and records survive from as early as the 8th century documenting the denunciation of guilds by Christian bishops for the swearing of oaths known as "conjurations" 4 which took place in an annual ceremony held on December 25 during the feast of Yule or Saturnalia.

"Let no one dare to take the oath by which people are wont to form guilds. Whatever may be the conditions which have been agreed upon, let no one bind bimself by oaths concerning the payment of contributions in case of fire or shipwreck."

-Carolingian Capitulary, 779 AD, (Brissaud:1915,239)

According to Church records, early efforts to Christianize these ceremonies were unsuccessful, leading to tension between the towns and the first estate, but the conflict between the guilds and the authorities gradually eased with the introduction of patron saints for each guild. Guilds seem to have become thoroughly Christian by the medieval period, at least on the surface, though some latent heathen overtones of many guild practices, especially during carnival, contributed to the inherent political hostility and distrust that remained between the towns and the Church.

By their nature, and in order to function properly, guilds seem to have to be independent, and organized from the ground up (Lucassen, 2009:12). Even in powerful states like the Ottoman Empire and the Venetian Republic, guilds were granted considerable autonomy in order to function (Lucassen, 2009:13). Conversely in other places such as India, where guilds had a long history, their development (and the correlative economic benefit) seems to have been slowed due to being suppressed by Mughal authorities who would not allow them any independence (Lucassen, 2009:13), although the caste system may also have been a factor. In Europe, though there seems to have been an opening for this independence, it was by no means easily established nor (at least initially) welcomed by the authorities.

\section{The dangerous world of medieval trade}

A passage from an interesting $15^{\text {th }}$ century account, excerpted and cited by Janssen and many others, gives us some insight into the early guilds. It is also a fascinating glimpse into the perilous life of a traveler at this time, including pitched battles against pirates as I will show later. Janssen believed that temporary arrangements of this type made for caravans and mercantile convoys were also the origin of the permanent seafarers' associations originally established centuries earlier in the towns, and these became the first merchant guilds.

"As we are surrounded by storms, high waves, pirates and other dangers, we must keep a strict order that we may bring our voyage to a good end. Let us commence with prayer, and sing canticles unto God, to obtain a fair wind and a prosperous voyage.

4 Con-juror, an oath of peers. A history of French public law, Volume 9, Jean Brissaud page 239 
Each one must be equal to each other, and according to marine law, we shall name the occupiers of the judges' seats (schoffenstellen)."

Thereupon the crew elected a vogt and four scabini, to act as their judges. The rules follow: Cursing is forbidden. No one is allowed to use the devil's name, to neglect prayer, to go around with lights, to waste food, to encroach on the rights of the quartermaster, to play dice or cards after sunset, to irritate the cook, to interfere with the sailors; all infringements of these regulations are punished by fines. Corporal punishment is meted out for sleeping while on guard, making a disturbance on board, using arms in a fight, for theft, and for other misdemeanors.]

At the end of the voyage the vogt and the scabini abdicated their functions and addressed the crew as follows: "What has happened on board ship, we must pardon to each other and consider as dead (todt un ab sein lassen). What we have judged right, was for the sake of justice. This is why we beg you all, in the name of honest justice. to forget all the animosity one may nourish against another, and to swear on bread and salt that he will not think of it in a bad spirit. If anyone, however, considers himself wronged, he must appeal to the land Vogt and ask justice from him before sunset." On landing, the stock with the fred-fines was handed over to the Vogt of the sea-port for distribution among the poor. (Janssen:1896:51) 5

\section{The merchant guild and the nascent urban community}

Initially the first true guilds in Europe played two roles, a social role in replacing the rural clans and a financial role as insurance associations for seafarers and traveling merchants. These early mercantile guilds were the basis of local trade pacts and treaties between towns and rural areas, such as in the Hamburg Lübeck Lüneburg zone, which led to the creation of the Hanseatic League. Many other smaller leagues of cities throughout central Europe arose on a similar basis.

Merchants typically formed elite "grand guilds" in most large cities in the $12^{\text {th }}$ and $13^{\text {th }}$ centuries (Dollinger, 1970:14,134-136). These were subdivided into different benches or banken on the basis of which region they traded with; for example, in Flemish towns, merchants associated with a particular commodity and who traded with London formed their own guild: wool merchants in one group, herring merchants in another, beer merchants in another and so on. Merchant guilds became elite organizations in the city, closely associated with the wealthy "patrician" class, which is sometimes confused with the nobility or called "urban nobles." These patricians dominated the political strata of the town and made up most of the magistrates, town councilors, and burgomeisters in the towns from the $12^{\text {th }}$ through the early $14^{\text {th }}$ century (Dollinger, 1970:135-136). Representatives from the merchant guilds also acted as diplomats and politicians on behalf of the town in regional political bodies including the Imperial Diet in the Holy Roman Empire.

Starting in the $14^{\text {th }}$ century the political power of the merchant guilds was threatened by uprisings from the craft guilds (Dollinger, 1970:136, Lucassen (Soly) 2009:60-61). In

5 The original source is cited as J.D. Wunderer, "Reisebericht", from Fichard's Frankfurter Archiv., II, 245., quoted by Jannsen, Geschichte des deutschen Volkes, i., 355 
some towns this coincided with merchant families forming trading companies which were sometimes bitter rivals with one another. Though these events could be bloody, north of the Alps there was often at least some restraint shown, if only to prevent the princes from taking over such as happened at Mainz. In Italy this not unusually got much more out of hand, leading to bitter civil and regional wars, especially between Guelph (pro-Pope) and Ghibelline (pro-Emperor) loyalties were in play. Ultimately this led to the downfall of many of the urban republics of Italy or their seizure at the hand of mercenary lords (signori) such as the Visconti or Sforza of Milan.

In central Europe there were also conflicts of this type but the merchants were better able to moderate them through loosely organized but effective institutions like the Hanseatic League. By the time of the opening of the Atlantic and Pacific trade routes, merchant guilds began to be replaced by the large trading companies.

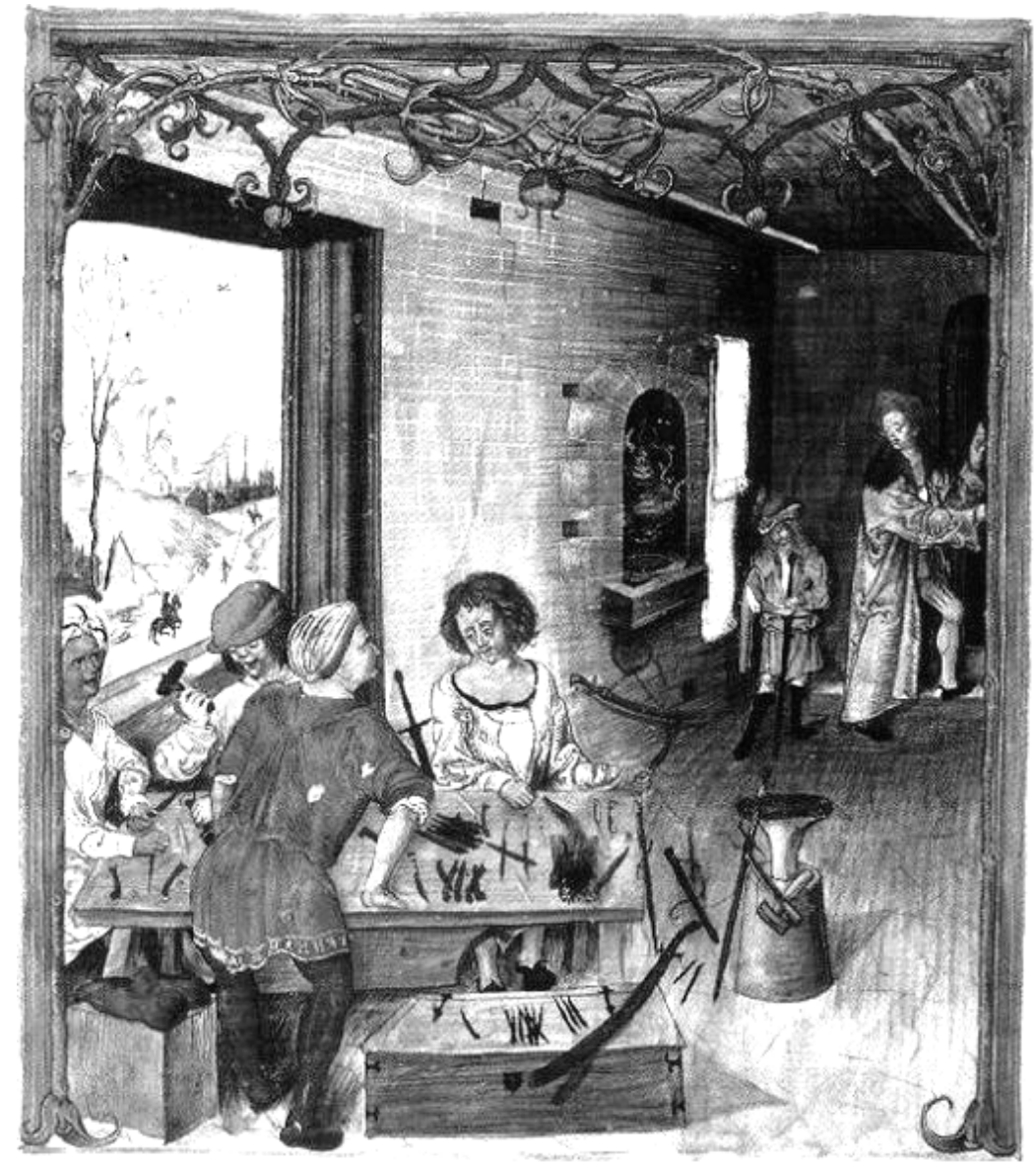

Cutlers' workshop, from the Balthasar Behem Codex, Krakow, 1505.

The apprentice or journeyman on the left appears to be a Moor or a Turk. 


\section{Craft guilds}

Most of the time when people refer to guilds in the general sense, they are talking about the craft guilds of the artisan class. The early craft guilds were organizations of artisans in the various industries of the town, which collectively controlled most production in the late medieval era and played a political role in the era's politics. The first hint of craft guilds appeared in Flemish, Italian and German records in the 10th century, though we are not certain of their development until the 12th (Epstein 1991:52). German craft guilds remained relatively marginal until the 13th century, however, when they became much more numerous and politically important (Lucassen (Soly), 58-60). Formal associations of urban artisans grew in strength all through the $14^{\text {th }}$ century and become a force to be reckoned with in Flanders and the German and Slavic regions by the $15^{\text {th }}$, which is essentially the heyday of the artisan classes in central and northern Europe (Lucassen (Soly):58-61).

The first really powerful craft guilds came out of the booming textile industry and its ancillaries; other important crafts included armor production, beer, ship building, and glassware. In many German towns, for example Cologne (1396), Dortmund (1399), Gdansk (1416), Wroclaw (1418) craft guilds either took over political power or achieved a power sharing arrangement with the patricians in the $14^{\text {th }}$ and $15^{\text {th }}$ centuries (Janssen 1896:140). The craft guild continued to exist in central Europe and some parts of northern Italy long after its peak of influence in the $15^{\text {th }}$ century in various forms, however, up to the French Revolution and, to some extent, even afterword.

The craft guild was a type of co-op business for the whole craft industry, which served four fundamental purposes: to provide the basis of mutual aid in a social and religious context for its members; to bargain with commercial partners on a wholesale level; to enforce quality and defend the reputation and market of the craft; and to transmit technical skills and innovation to its membership through effective training. The craft guild was like a trade union in some ways, but also quite different because it was essentially an association of business owners, with the ordinary laborers (apprentices and journeymen) enjoying at least the realistic prospect, in most cases, of becoming owners themselves. 


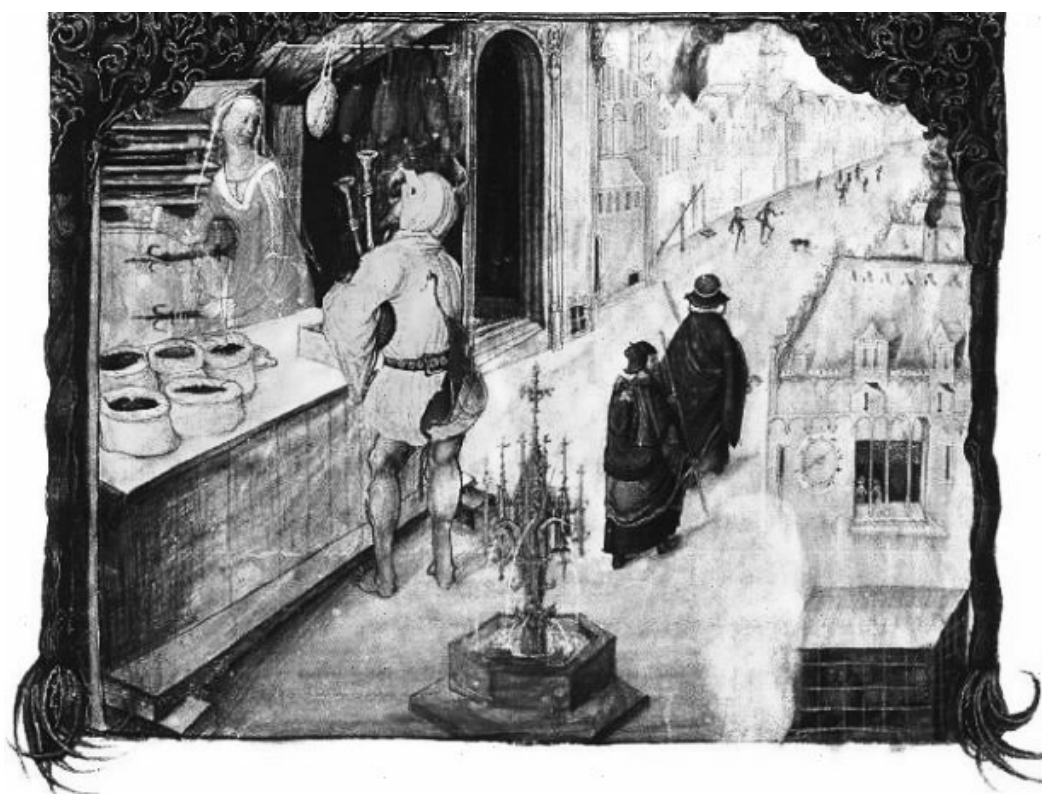

A shopkeeper, Codex Picturatus, Krakow, 1505

\section{Structure of the craft guild}

One of the revelations of the new research is that guilds in general, and craft guilds specifically, did not follow one particular pattern, but rather loosely adhered to a range of patterns, frequently changing their configuration according to the political and economic circumstances. Medieval craft guilds had three basic ranks in their hierarchy: apprentice, journeyman, and master. In addition, masters could become guild aldermen, or even judges or city councilmen, if they rose high in their craft, and if their craft was sufficiently important.

Only the full members of the guild, i.e. the guild masters, were normally considered full citizens of the town. These people, men and women, represented the middle and upper middle class (Dollinger 1970,133). But it was not a static middle class. As the towns gradually expanded over time, a steady stream of immigrants from the rural areas moved into the city and joined the guilds. By the $15^{\text {th }}$ century this process gradually changed the ethnic composition of the towns in eastern Europe and the Baltic from mostly German to higher percentages of the local Scandinavian, Slavic or Baltic rural populations (Dollinger:131). Apprentices and journeymen fully expected to move upward in economic and social status and one day become masters. How many actually did so depended greatly on the local economic status of their craft and the politics of the town. More often than not during the economic boom of the late medieval period, social mobility was brisk, though this declined in the $16^{\text {th }}$ century (Janssen 1896:133).

Between and within the guilds themselves, however, all was not equal. Though there were strict rules governing how guild workshops could be operated, there was also 
constant pressure to work around and abuse these rules (Epstein (Soly), 2008:82-84). Guild workshops were limited to employing only journeymen and apprentices who had been accepted by the masters according to guild law, in theory, and in the amount of equipment such as looms, brewing vats, forges etc. they could have in the workshop (Epstein (Soly):83).

One way around these limits was subcontracting, which could be a means for wealthier artisans to make a lot of money from the work of poorer artisans (Epstein (Soly):81113). But it was also a means by which work either on a very large scale or very high quality could be done through specialization (Epstein). Another way around restrictions on the size of a workshop was by allowing the wives, servants, and or children of the master artisan to work formally or informally and illegally (Lucassen (Crowston) 2009:28-29, Epstein 2008:10). This was closely linked to the complex issue of women in the guilds, their membership status and pay and so on, but that is unfortunately beyond the scope of this paper.

In a given town, there was also a hierarchy of guilds by craft (Dollinger 1970:137). The most prestigious were the makers of luxury goods: jewelers and goldsmiths, silk weavers and amber carvers, and so on. These guilds often had special privileges and rubbed elbows with the patricians and nobility; a tax roll of Hamburg in the late $15^{\text {th }}$ century showed families at this level owned the considerable sum of 2,000-5,000 Lübeck marks in property (Dollinger 1970:133). The second most prestigious were guilds involved in the largest or most prosperous craft industries which therefore had the most political and economic, (and military) muscle. The Hamburg tax roll showed butchers and goldsmiths had between 600 and 2,000 marks (Dollinger:133). In the large towns of the Rhineland and southern Germany textiles were often the biggest industry, and the weavers', fullers', and dyers' guilds held enormous political power from the $14^{\text {th }}$ century through the mid-16th (Lucassen (Soly):2009:59).

Just below that level, making up the middle class, were the other important guilds such as the bakers, furriers, masons, carpenters, printers, cutlers, innkeepers, shipmakers, and so on, who in the Hamburg tax roll possessed 150-600 marks in property (Dollinger:133). Then came the more prosaic guilds such as cobblers, shopkeepers, bakers, street sweepers, and tinsmiths; and finally the marginal guilds which sometimes came together to form "grand guilds." It is also important to note that each craft was not always in its own distinct guild. Quite often several crafts which did business together would be combined into the same guild, sometimes seemingly unrelated crafts did so as well.

All of these guilds were in a constant pushing and shoving match for political and economic power between the crafts, internally inside each individual craft, and between the crafts and the merchants who dealt in raw materials and money (Epstein (Soly), 2008:82). The town council was also always kind of a faction unto itself regardless of whether it was a guild or patrician town. It was also the case in certain towns that the richest merchants came out of the ranks of the artisans themselves; this was the case with both the Fuggers and the Welsers in Augsburg, for example (Johanek,2000:7). This meant that there could be a wide range of wealth within the craft guild itself (well beyond the figures quoted for Hamburg above). 


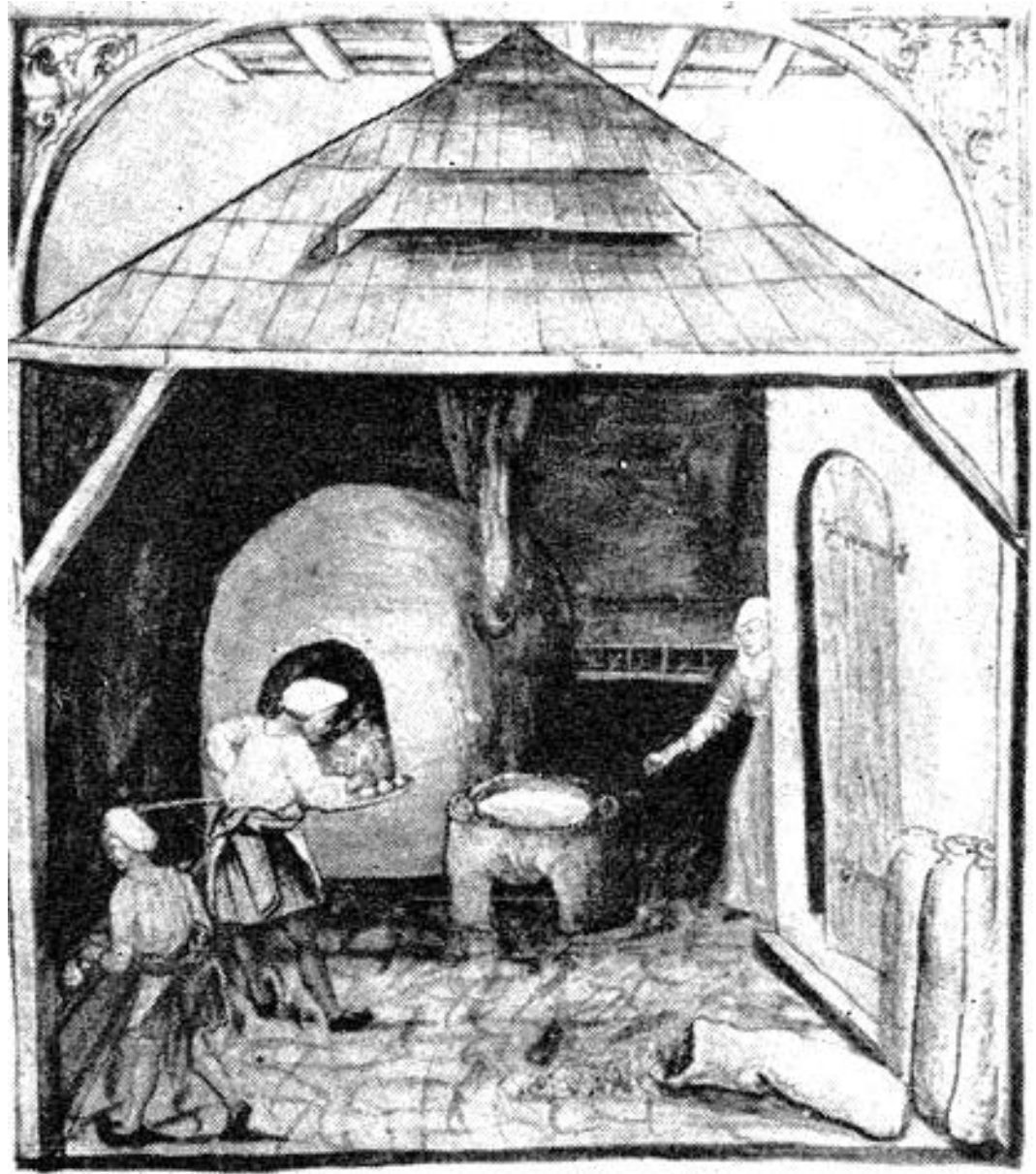

Bakers' guild workshop, Balthasar Behem Codex, Krakow 1505

Apprentices made up a significant percentage of the laborers in most towns (Epstein 1991:65). An apprentice was essentially the temporary indentured servant of the master, who sponsored limited citizenship and literally took them into his or her family. It was a great privilege to be taken in as an apprentice for most because it represented the potential for social mobility and a path to becoming a citizen. On the other hand if they ran away they could be banned from the craft for life (Janssen 1896:22).

Apprentices were unpaid except for room and board, clothing, and some pocket money while they learned their trade. One of the most contentious issues for guilds was whether apprenticeships had to be completed in every case, or if it was possible for relatives of guild masters, or merchants' sons, or just anyone with the money to buy an apprenticeship without having to go through the arduous process of years of hard work (Epstein 2008:62). Widows in towns in Flanders, Bohemia, Germany, and northern Italy 
were typically given a dispensation to practice their husband's craft if he died, and received full guild privileges (Epstein 1991:211), and marrying a widow was one of the few ways to get around the normal restrictions to membership.

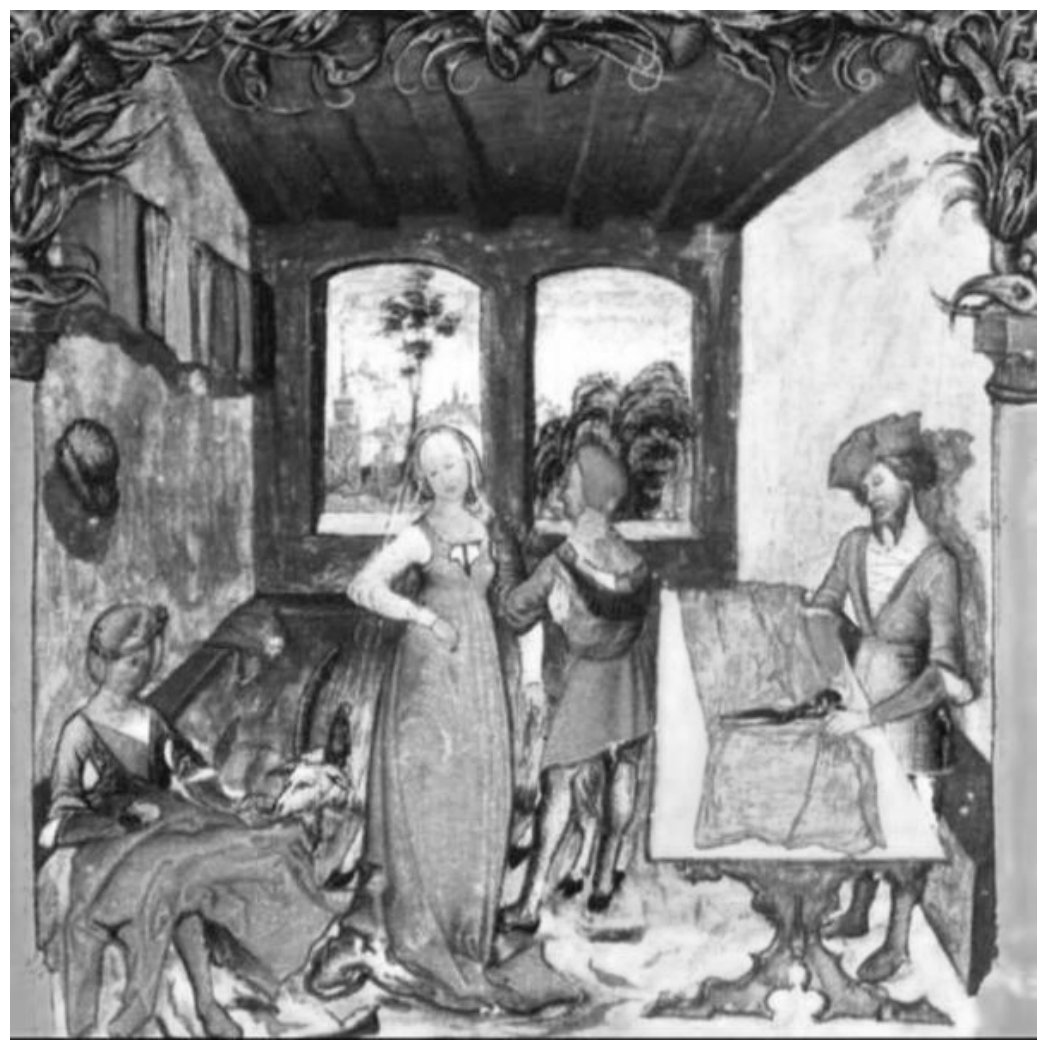

Tailors' workshop, from the Codex Picturatus, Krakow, 1505

When this law was changed it could mean that the guild had been "captured" by the merchant or patrician class, who could then buy their way into the guild without actually doing the work. Conversely, as Ogilvie pointed out (Ogilvie, 2008:175-182), guilds could extend the length of time of an apprenticeship far beyond what was needed to learn a specific craft, in order to slow down their growth during lean times, or to take advantage of free work from apprentices. In order to combat this, apprentices formed their own societies together with journeymen starting in the $15^{\text {th }}$ century, as we shall see.

\section{Journeymen}

After completing apprenticeship, the young craftsman became a journeyman, and was considered a competent worker and exponent of the craft, but not yet qualified as a master. In most crafts, journeymen had to leave their home town to spend their journeyman years, known as wanderjabre or auf der walz sein, traveling the world with other 
gesellen ("road-companions" (Epstein (Reith) 2008,114). The rules varied both by craft and by region, but by the middle of the $15^{\text {th }}$ century young journeymen in the Germanspeaking parts of central Europe typically had to remain away from home through this entire period, usually lasting between a year and a day to three years and a day. During their wanderjabre they carried a log book called a wanderbüch which was stamped at the guild-house of each city they visited.

When a journeyman entered a new town he or she had to check in with town authorities and the local guild, present the log book, and try to find work. Journeymen established at work in a foreign town were in a somewhat ambiguous position. On the one hand, they were outsiders, but on the other, they had a fairly high status as respectable burghers, and they made up a substantial part of the population, on average about seven percent overall and about twenty percent of the active working adults (Lucassen,2009:115-117). They also remained linked to their own guilds back in their own home towns, which gave them a certain diplomatic cache as representatives of their home town and guild.

Journeymen were normally held to a high standard of behavior by the guilds and by their own journeymen's associations, and there were many traditions set up to enforce the stability of this curious system. For example before setting off each journeyman was given an earring which could be ripped out if they disgraced themselves on the road, leaving a scar to mark them for life. To prevent imposters from infiltrating their ranks, journeyman were taught secret handshakes, signals, signs and marks that were traditionally used to identify each other (Janssen,1896:30).

On the road journeymen had a special status, generally tolerated by the authorities and permitted entrance into the towns and villages. While tramping journeymen stopped at farms or villages and worked for peasants in exchange for room and board. This practice put them on relatively good terms with the rural populace, who provided places to sleep in the stables, gave rides on passing carts and so on. Generally the journeymen helped reinforce affinity networks between town and countryside. The constant circulation of journeymen between towns in central Europe also contributed to the spread of technology from region to region, town to town and guild to guild (Epstein (Reith),2008:123), and was one of the factors which helped establish fraternity between the cities of Europe beyond national and even ethnic boundaries.

\section{Guilds, journeymen, and social mobility}

As recently as the 1970s many academics still believed that medieval society was essentially static and that people in this period lived relatively parochial lives (Lucassen,2009:115-117), seldom straying far from home. But in more recent years this has been thoroughly debunked (Lucassen, 2009:115-117); in fact it seems that it could not be farther from the truth. Mobility in general was much greater than previously estimated in medieval Europe, and journeymen in particular tramped all over Europe, and even into Ottoman Turkey and places in central Asia. Epstein pointed out one 
example in Vienna in which of 4,773 guild masters, only 1,160 (roughly 25\%) had been born there; the rest had come from other places via the journeyman system, and a third were born outside of Austria (Epstein, 2008:16).

Women journeymen also traveled the roads in at least some cases. Records from Zwickau in 1531, for example, show that the municipality registered female journeymen, called Kämmerinnen, about two thirds of whom came from within a $50 \mathrm{~km}$ radius (Epstein (Reith), 2008:121). Under this system labor went where it was most needed as journeymen gravitated toward places where their craft was thriving and they could find work. This was an important aspect of the flexibility of the guild system.

Journeymen worked long hours, typically from dusk to dawn, making for a twelve-hour day in the summer and a ten-hour one in the winter (Schildhauer,1988:159-160), depending on the specific region of course. They took two long breaks for lunch and supper, however, with meals usually provided by the customer or the guild master (Janssen,1896:31-33). They had half a day off per week, which could be Monday or Saturday, when everyone typically went to the public baths (Janssen, 1896:33-35), as well as Sundays and unpaid vacation on all holy days, of which there were between 80 and 120 per year depending on the place and the specific time. They also could receive a handful of paid days and extra half-days off, on a few of the major saint's days and if they were sick (Janssen).

Journeymen were paid more than the pittance given to apprentices, but it was still much less than the going rate for a master craftsman (Schildhauer,1988,160). In fact one of the ways guild masters made money is that they were paid a full wage for each person in their workshop. Starting in the $15^{\text {th }}$ century, when staying in a foreign town, the journeyman joined the local journeyman's club, a special hall for journeymen and apprentices (Epstein, 2008:63). These clubs, which were run either by the guilds or by special journeyman's benevolent associations, maintained hostels which could provide the young journeyman out with a place to sleep, a meal and a "traveling penny" if no work was available. If a journeyman fell ill he or she would be taken in by the family of a guild master and cared for until he or she recovered (Janssen 1896:25).

\section{Journeymen and labor unrest}

Not everything was convivial between the guilds and the journeymen, though. Johannes Janssen gives us an interesting look at the sometimes fraught relations between journeymen and guild masters. Strikes were not uncommon (Janssen, 1896,31). In most cases they would be settled amicably by arbitrators; for example, when the shoemakers' journeymen of Emmerich went on strike in 1469, the city authorities mediated a settlement, and the two groups (journeymen and masters) had drinks: "after much discussion, through mutual concessions peace was re-established, much to the joy of masters and workers, who drank together and were as good friends as ever." (Janssen,1896:31) 
A strike of journeymen of the tailor's guild in 1503 in Wesel am Rhine over better food, pay and conditions was arbitrated by the burgomeister. His noted that "the journeymen of the tailors are more restless and more inclined to disturbance than others, but the masters are also to blame because they overpower the journeymen with work and do not give them three good meals in a day." (Janssen, 1896:31). He also threatened fines to the guild masters if they slapped or pulled the hair of journeymen who had refused to work on Sunday or on a Holy Day (Janssen, 1896:31).

But it wasn't always that easy. An unresolved dispute between the journeymen and masters of the tinsmiths' guild in Nuremberg in 1475 after a wage cut resulted in the eventual decline of the tinsmithing industry in that town. A group of journeymen tailors on strike in Metz in 1505 were blacklisted and banished from the trade. Nineteen towns were on the lookout for an agitator named "Henry Ruffs of Worms" (Janssen:30) who was stirring up journeymen in several towns.

A lot of the labor trouble was about food. A coordinated strike by the powerful association of watermen in several cities of the Rhine in 1469 left us a rather amusing complaint from ships masters made to the Margrave of Baden: "...although receiving a florin a day, they are not contented at their meals with a soup, a good vegetable, together with meat, bread and cheese, but demand also a roast and dessert. This seems unreasonable, we cannot afford to give all this." (Janssen:31) Whether this represents the actual situation or just poor-mouthing by the guild masters is hard to say.

There was always potential for such conflicts to get out of hand, since journeymen like all free men carried arms and knew how to use them. The shoemakers' guild in Leipzig got into a dispute with the university and challenged the doctors and masters to "show the reason why they carried arms and to defend the honor of the profession." (Janssen:24) It is unclear if the scholars took up the challenge. We also have a Frankfurt city council regulation in 1511 declaring that "on account of the riots, hereafter no master or journeyman belonging to the shoemakers' guild shall carry a sword or dagger longer than that which was designated on the Roemer." (Janssen:24) 


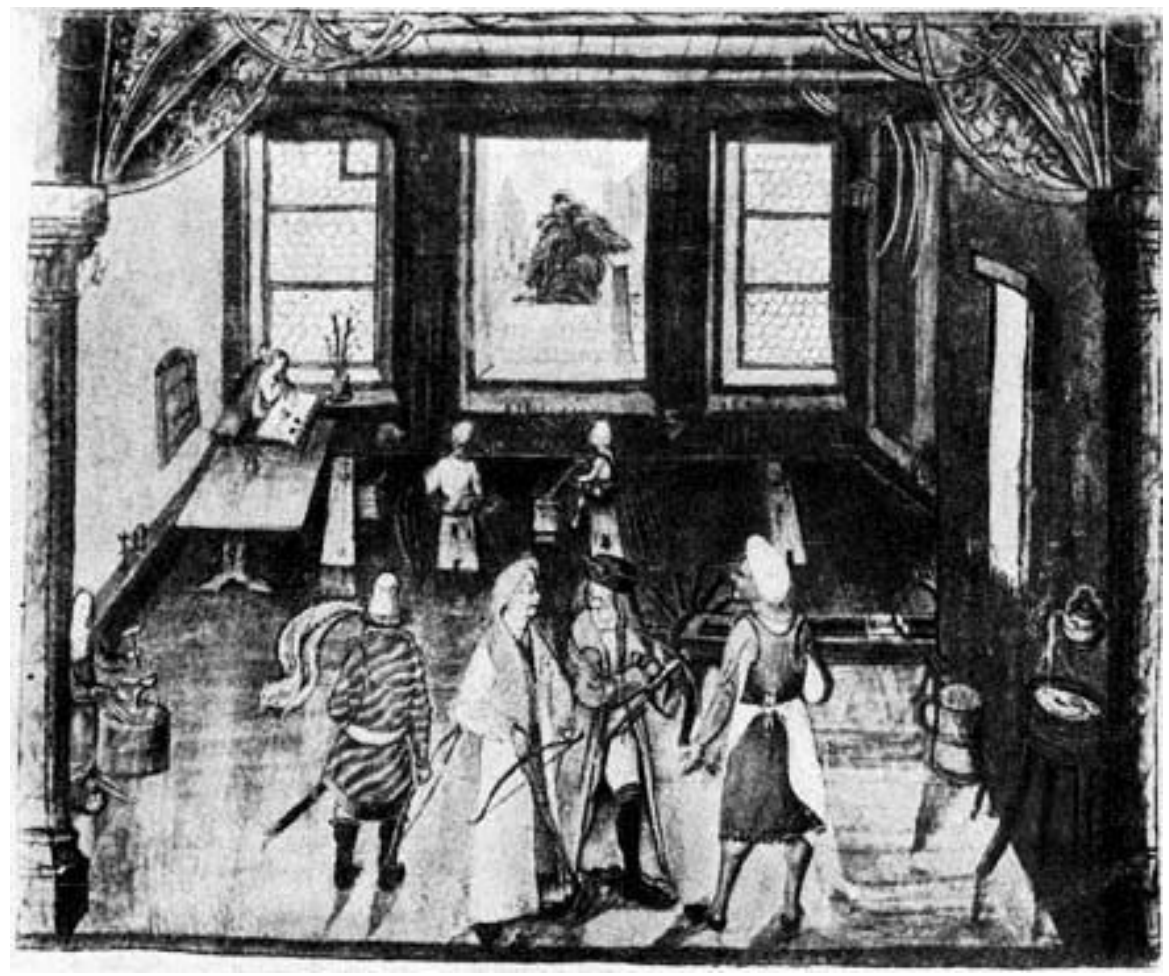

Crossbow-makers' workshop, Balthasar Behem codex, Krakow 1505 AD

\section{Quality control}

Craft guilds had strict rules for quality control, including inspectors who protected the consumer and thereby the reputation of the craft. For the craftsman, their work was both sacred and a form of art, and their tools were passed down with great care from one generation to the next (Geis, 1994:124). The quality of artifacts and architecture from the medieval era is remarkable.

In the laws for the inspection of meat it is ordained that when a cow or bullock is killed two or four judges shall decide the value of each pound- three or two pennies. The price and the quality of the meat shall be notified on a board, so that the customers, (like so many fools) may not purchase cow for bullock meat.'

-Excerpt from the butchers' regulations at Nuremberg, $15^{\text {th }}$ century (Janssen, 1896:16)

Butchers were forbidden to be cruel to the animals they slaughtered. Danzig butchersguild regulations forbade the smothering of animals killed for the market; they had be stabbed in the neck, somewhat like the practice of a kosher or halal butcher today (Janssen,1896:15). Dead calves too young for butchering were thrown away, and meat 
had to be clearly labeled including when it was slaughtered. It was forbidden to mix different types of meat.

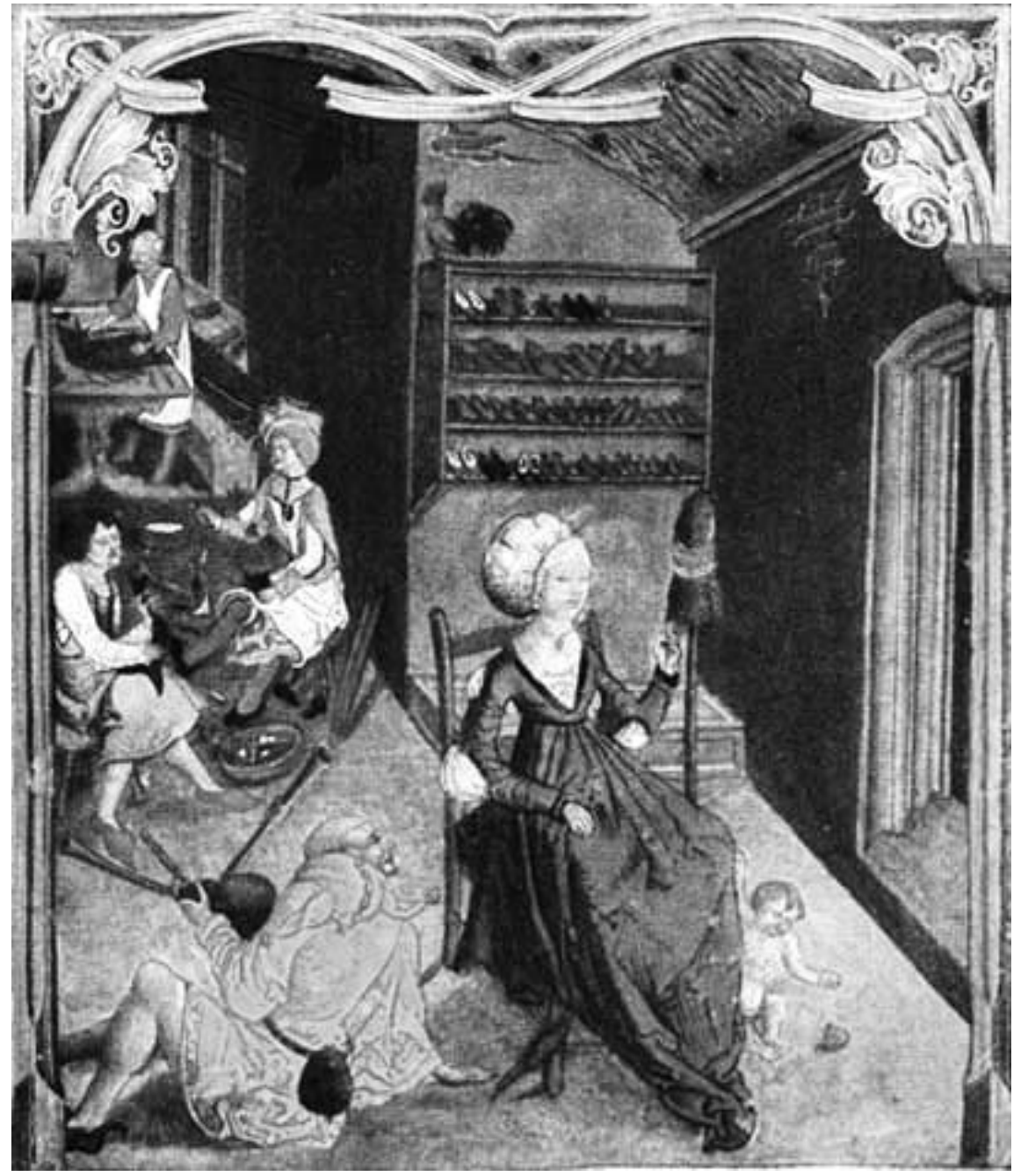

Shoemakers' guild workshop, Balthasar Behem Codex, Krakow 1505

Wine found to contain birch, sulfur, clay, eggs, milk, salt, chalk, or any other substance was banned, because as it says under the Basle guild law "each wine shall remain as God made it grow" (Janssen,1896:16). All commodities had to be properly graded and labeled, and different grades of materials were carefully regulated. In $15^{\text {th }}$ century Augsburg, for example, there were six different grades of bread (Janssen,1896:16). The legacy of this tradition of careful quality-control can be seen throughout modern Europe today, in German and Czech beer laws for example. 
Rules were also established for the room board and clothing of apprentices. The Strasbourg carpenters guild law of 1478 for example stated that the master was obliged “... to give his apprentice, besides his salary of four marks yearly, shoes and white stockings, four yards of grey cloth for a coat, four yards of ticking for a smock; he must also give him an axe, a saw, a rule, a gimlet, and finally, at the close of every week, two pennies pourboire [spending-money for a beer or a visit to the public baths on Saturday]" (Janssen, 1896:21).

\section{The rivals to guilds: the putting-out system}

The most serious threat to the craft guilds was posed by the verlag and the simpler kaufsystem or putting-out system (Epstein, 2008:86). Merchants, princes, and prelates set up expensive machines and large carefully organized sweatshops which made it possible to use unskilled labor to compete directly with the craft guilds. The workers could be poor peasants given hasty training, or the servants of local gentry, or monks or nuns from a local convent (particularly when more highly skilled labor is needed) or even foreign slaves or captives.

Most medieval cities had multiple municipalities which fell under different town charters as well as churches and abbeys which were immune to municipal authority on their own property, and the latter took advantage of this to break guild monopolies and the trade monopolies of the merchant "patricians." So long as this went on at a certain scale it was tolerated and did not disrupt guild business (Epstein, 2008:83), because the guilds typically controlled the export markets and the upper part of the local market for the top quality goods, while the "bunglers" (as they called non-guild artisans) usually had the lower end of the local market. If the suburbs or the abbeys started dumping cheap imported products on the market the way say some nations do in the US today, the guilds and/or the town authorities would intervene and there could be civil unrest, bloody riots, or even regional wars.

Putting-out systems were often organized in the countryside, in literal "cottage industries," although the guilds also had similar subcontracting systems in the rural areas which were integrated into their own workshops (Epstein, 2008:87). Much of the economic history of Europe has been defined by a back-and-forth struggle between organizations of skilled artisans, i.e. the craft guilds on the one hand and, on the other, the merchants, patricians and nobles for whom the putting out system was more convenient. Whether the former or the latter took precedence in a given area had to do mostly with the faction that controlled the town council, and how strong the town itself was politically and financially.

\section{The guild sodality and benevolent association}

The guild was also a patron of charity and public works. They helped build new buildings and public water systems in the cities, repaired buildings damaged by fires, improved the town walls (for example, guilds built all the towers of the town walls in 
Krakow: the main gate is still called the furriers gate (Lepszy,1912:48)), and bought or made arms for the town militia (Chandler 2013:118). Much of this type of activity, especially the charitable work, was organized through a variety of religious societies, carnival clubs, and secular "benevolent associations."

These groups commissioned art and church choirs, funded alms-houses, hospitals and cemeteries on behalf of widows, orphans, and the poor, and paid for Christian burials for their own membership and for the poor. At the turn of the $16^{\text {th }}$ century there were over 70 such associations in Lübeck, 80 in Cologne, and over 100 in Hamburg Janssen, 1896:11). Their goal was the social welfare of the city, and to enhance the glory of their craft among their fellow citizens.

From the mid- $15^{\text {th }}$ century onward, much of the intense social activity in central Europe during carnival was sponsored by these "benevolent societies" formed both by the guilds and the journeymen's associations (Janssen, 1896:26) in addition to other social societies which were not affiliated with guilds. Johannes Janssen lists town records from Frankfurt am Main that document the typical pattern of the formation of these groups in the central European towns: the banner-bearers' benevolent association was founded in 1440 , those of the shoemakers and tailors in 1453, of the painters in 1455, of the butcher-boys in 1455, and of the cotton weavers in 1460, and many others were founded about the same date (Janssen, 1896:26). The emphasis on charitable work derived from a common belief at the time that prosperity without charity was usury. The origins of this idea may have been from St. Augustine, who wrote that wealth earned by the work of the hands could be considered usury. (Janssen,1896:9).

\section{Processions and parades}

The guild fought hard to maintain its honor. One way this manifested itself was in annual processions during Carnival and on saints' days. In Krakow, on Corpus Christi Day and also on all coronations, all the guilds marched in order of prominence with swords bared, to emphasize the role they had previously played in the town defense, but also to make a point about the power relations in town (Lepszy, 1912:48). It was the same in Germany. The bakers' guild of the town of Colmar suspended baking for ten years beginning in 1495 when it was excluded from the annual procession of Corpus Christi, depriving the town of bread until 1505, when the guild paid a fine of 166 florins and got back its position in the parade (Janssen, 1896:30).

Janssen described how these groups held colorful and elaborate processions on Carnival and on other major saints' days (such as Corpus Christi). For example on Carnival Day the companions of the shoemakers' guild in Nuremberg held a "bath-walk." Meeting at the guild-inn they marched in white bath cloaks and hats, accompanied by fife and drum, through the city to the public baths and back to their inn, where they regaled themselves (Janssen, 1896:26).

These celebrations were typically combined with charitable acts. On New Year's Day the bakers of Freiburg went in procession through the town carrying an enormous cake 
(bresel). A beautifully dressed Christmas-tree was shaken by the oldest member for the poor, who gathered up the cakes and fruits that fell from it. Wine was distributed to everyone, and the day was closed with dancing (Janssen, 1896:27). Costumes were elaborate and flashy. Members of the cooper's guild danced their hoop dance dressed in red cotton stockings, fine white shirts, and green Hungarian caps with bands on the side. In Hamburg the brewers celebrated every two years what they called the hoge, which lasted a full eight days, and consisted of public processions, dancing, and sports. This may be where the famous "sword dance" comes in, about which more in a moment.

\section{PART II: THE ARMED GUILDS}

We now come to another expression of guild organization which has not yet seen much if any analysis yet in the new literature on guilds: the armed or martial societies. I have tentatively defined four different types. The first two, showing up in the $13^{\text {th }}$ century, were the armed societies, of which there seem to be two sub-types, one dominated by the craft guilds and one by the patricians. These took on an important social role but also formed the basis of the town militia and the town navy. The third type was the shooting society which appeared in the $14^{\text {th }}$ century. The fourth type was the fencing or martial-arts guild, the first of which can be dated with certainty in the $15^{\text {th }}$ century.

\section{Patrician military societies}

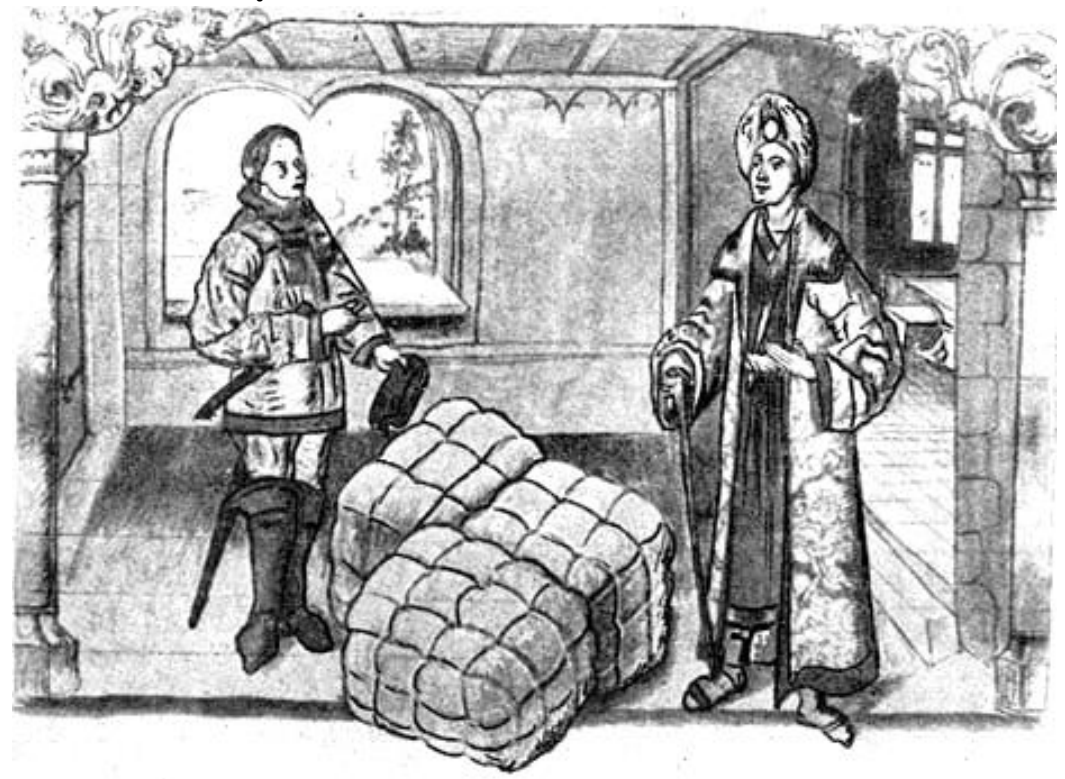

Merchants' guild, Balthasar Behem Codex, Krakow 1505. The man on the right is a Polish noble. 
Unlike craftsmen, who made products and let others worry about how to get it to market, merchants had to move goods across long distances to make their living. In medieval times, lacking railroads or highways, the principal method to move heavy cargo was by ship or boat. Using the rivers, coastlines, and eventually the open sealanes, trade could be remarkably efficient and took place on a surprisingly large scale. And yet maritime trade remained an extremely dangerous and quite often bloody business. Wars were common as feudal princes struggled with each other, and with the free towns, for control of various markets. And as we have already noted, in addition to the more prosaic hazards of storm, fog, and tide, pirates were a major threat.

The stakes in naval warfare could be very high. The mayor of Lübeck was executed for losing a battle against Denmark in 1362 in which he lost twelve war-cogs, captured while the bulk of his forces were on land (Schildhauer, 1988:46). King Valdemar IV mocked the Hanse shortly afterward, saying "Seventy seven hansas have seventy seven geese; as long as the geese don't bite me, I don't give a damn for the hansas!" German merchants were bullied and the herring market suffered. Then in 1367, 57 towns met at the confederation of Cologne which voted to go to war against Denmark, starting in 1368 (Schildhauer, 1988:47). Copenhagen was sacked and burnt to the ground, much of the east coast of Denmark was depopulated, and Scania, home to the herring fisheries, was captured. The geese bit. The treaty of Stralsund in 1370 was a humiliating blow to Denmark; among other things it granted four key fortresses in the Orseund to the Hanse and stipulated that the election of the next Danish king was subject to Hanseatic approval (Schildhauer, 1988:48).

But there was still trouble for the Hanse merchants. In the north and Baltic seas where the Hanseatic League was born, commerce was threatened by large pirate groups such as the Vitalenbruden and the Likedeelers with entire fleets of warships (Dollinger, 190,79). Smaller groups of Swedish and Karelian pirates haunted the estuaries of the Neva river (Dollinger, 1970:27), threatening trade from Novgorod, and the coastlines of England and Scotland were infested as well (Dollinger, 1970:302). Of course it was also often the case that one man's pirate was another man's freedom fighter, and during wars towns openly made use of both pirates and privateers. For example in 1389 the city of Mecklenburg, supporting their duke in a war of succession with Queen Margret of Denmark, declared brazenly that they opened their ports "to all those who at their own risk would go to sea to harm the kingdom of Denmark" (Dollinger, 1970:79) making them into a kind of medieval European Port-Royal. Wisby, Rostock, and Wismar also became havens for pirates, and oriented their workshops toward outfitting and supplying pirate ships.

These pirates preyed upon Hanseatic vessels as well, and the Hanse, initially just Lübeck and Stralsund, fought the pirates by building heavily armed escorts (called Orlogschiffe or Friedenskoggen) and organizing their trade voyages into convoys. As the price of herring went up to uncomfortable levels, more Hanse towns got involved, and in 1395 seven of them organized a truce between the warring factions and took control of Stockholm as 
custodians (Dollinger, 1970:80). This did not end the piracy, though, and by 1400 the Teutonic Knights joined the campaign against the pirates and successfully attacked their largest base at Wisby with 4,000 men and 84 ships (Dollinger, 1970:80). But once unleashed on the world, piracy is hard to stamp out, most of the pirates had simply moved to other bases, so the raids continued.

Finally, in 1402, two Hamburg city councilmen (ratsherren) Nicholas Schocke and Hermann Lange, both almost certainly merchants from the patrician class, led a fleet of ships which captured the infamous pirate Stortebecker in 1402. Their flagship was called the Bunte Kub (colorful cow). A large number of the pirates were executed shortly afterward, ending a forty-year reign of terror by the Vitalenbruden (Dollinger, 1970:264). This diminished the problem to more manageable levels, but even after that, piracy remained bad enough that the Hanse continued to use armed convoys for nearly all their commerce through the Oresund and in the Baltic - their main source for furs, grains (from Poland via Danzig), and iron (from Sweden) as well as one of the principle routes for silk via the Silk Road.

Nor was such conflict unique to the open seas by any means. Trade along the rivers of central and northern Europe could be just as perilous. In his magisterial The German Hanse, French historian Philippe Dollinger gives a gripping hint of the hazards of river travel in the $15^{\text {th }}$ century:

River travel, though less dangerous than sea travel, nevertheless exposed sailors to similar risks. In the event of war between the rulers of lands bordering the river, boats were often attacked. Again it is only on the Vistula that a systematic defense organization existed, at least in the mid-fifteenth century, at the time of the Thirteen Years War between Poland and the Teutonic Order. The Prussian towns and nobility having placed themselves under the protection of the king of Poland, the Order attempted to interfere with river traffic. Danzig and Thorn (Torun) then decided to organize convoys, escorted by warships and provided with cannon and mercenaries. Several times in 1459 and 1460 fleets of more than 100 barges traveled from one town to another, skirmishing all the way.

(Dollinger, 1970:150)

So in order to thrive, the merchants had to reduce the risk and cost of trade, and this more than anything else required efforts made against piracy on the seas and along the rivers. But in addition to piracy on the high seas, merchants faced banditry in the misty forests and lonely roads. The initial attempt to control this in the $13^{\text {th }}$ century was called the Peace and Truth of God movement, a kind of medieval Geneva Convention, intended to impose some limitations on knightly warfare. This was enforced with marginal success by the powerful prelates (bishops, archbishops, and abbots), who controlled the early urban polities.

As the towns became independent of their rulers, however, and the rulers themselves became more unruly and aggressive toward the towns, it was the merchants, via their 
guilds, who enforced the peace. This came about in the form of treaties between towns, friendly princes and prelates, leading to local law codes which came to be known as the Landfrieden (Landfrýdy to the Czechs) or "peace of the roads." In the Baltic there were also more temporary pacts between towns which were called tohopesaten ("standing together") (Dollinger, 1970:107) which were able to fend off the aggressions of the princes in certain areas but didn't last long beyond that.

This often put the urban merchant class in direct conflict with the second estate, since most of the banditry, kidnappings, and excessive tolls were instigated by so-called raubritter or robber knights (Delbrück, 1920:247-251), and by feuding families of nobles who conducted war against one another by destroying one another's estates. The necessity of dealing with this led to the increasing militarization of merchant culture, and by at least the $14^{\text {th }}$ century the merchants themselves formed a cavalry arm of the militia in their towns and created armed societies which were among the earliest of the documented paramilitary guilds. The efforts of the urban forces were somewhat successful: by one estimate the towns in the Holy Roman Empire destroyed over 100 castles of robber knights in the late $14^{\text {th }}$ century alone ${ }^{6}$.

Nevertheless, the roads continued to be dangerous. Merchants developed an interest in chivalry which quickly became institutionalized, and the societies they formed became permanent fixtures in the Hanseatic, Free, and Imperial or Royal towns. These went by a variety of different names: in Strasbourg, Magdeburg, Zurich, Nuremberg and several other towns they were called konstoffler or constaffler (Delbrück, 1920:365). In Lübeck, Aachen, and Braunschweig (Brunswick) the armed patrician society was called the Lilienvente. The Brunswick Lilienvente fielded an impressive 402 lances in the 1435 (Menzel, 1858:62, Eltis 1989:6) and though Brunswick was not a Free City by charter, the patricians were sufficiently powerful to have pushed the princes of BrunswickWolfenbüttel out of the city by 1432 (and they didn't regain control of the town until the $17^{\text {th }}$ century).

One of the better documented of these societies was the so called Brotherhood of the Blackheads (Bruderschaft der Schwarz̧äupter) of Livonia. These were patrician military societies founded in several (at the time predominantly German-speaking) towns in what are now Finland, Latvia, Lithuania, and Estonia (Rannu, 1990:26). The first was in Tallinn (at the time known as Reval), then in Riga, Tartu, Haapsalu, Narva and the German town of Wismar (Rannu, 1990:27). Though it is unclear if it was their founding date, the first records of this society derive from the St. George's night uprising of 1343, in which native Estonians attempted to evict the German crusaders from their midst. Tallinn at the time sustained a siege, and from that point onward the Blackheads formed an elite cavalry arm of the town militia (Rannu, 1990,27-28).

6 Robber knights castles destroyed by town militias, Osprey publishing, German Medieval Armies, 1300-1500, page 9 
The term "Blackhead" derives from the seal of the association, which depicts their patron, St. Maurice (Rannu, 1990:27), an Egyptian soldier typically portrayed in Europe as a dark-skinned African. St. Maurice (also known as St. Mauritius) was very popular with military orders in Germany and central Europe. The Schwarzhäupter were made up of young unmarried merchants, equivalent in this sense to journeymen, and as a rule they had not yet joined the Great Merchant Guild (Rannu, 1990:28). Certain craftsmen, notably goldsmiths, were also admitted into the society, as were scholars and ships captains (Rannu:28).

Granted special rights by the town council in 1407, the Blackheads continued to play an important, even crucial role in the towns defense through the 15th and 16th centuries, and purchased arms for the town armory. For example in 1526 the Blackheads purchased eight "stone throwing machines," twenty cannon carriages, and sixty-six small caliber guns for the town armory, and contributed a further fifty gulden for the forging of cannons. The letter accompanying the gift stipulated that the coat of arms of the brotherhood would be stamped on the cannon barrels (Rannu, 1990:28). The Blackheads also played a critical role during the brutal Livonian War, proving decisive in a battle in 1560 and repelling two major sieges by the Russians in 1570 and 1577 .

The halls of these patrician societies developed a chivalric fame all their own. For example in Danzig/Gdansk, Torun, Elbing, and the other German-speaking towns of Prussia, the merchants' guild hall was known as the Artushof (Artus Court or "King Arthur's Court") and even featured a round table. The Artushof housed six fraternities organized as banken (benches). The St. Christopher's bench or the Lübecker bench, founded in 1482, was an association of Danzig and Lübeck Merchants (Simpson 1900:36-44). A Dutch bench was for people trading in the Low Countries. The Reinholdsbank (named after a fictional knight named Renaud de Montauban) included Danzigers, Poles, and native Prussians. 'Marienburger' was founded by veterans of The Thirteen Year War, who participated in the sieges of Malbork in 1457 and 1460, and finally there were the Biblical Magi, and Councilors (Simpson). At least one town councilor of Gdansk, Paul Benacke, was involved in a successful war against England and a daring, well-documented naval action in the $15^{\text {th }}$ century as commander of the formidable warship Peter Von Danzig (see Chandler:2013,126).

The patricians were armed and equipped like knights, and are often confused for knights in military histories (Delbrück, 1920:365) though the higher nobility despised them and took steps to exclude them from the most fashionable royal tournaments. These patrician societies continued to form the cavalry arm of the town militias, even after the patricians lost power to the craft guilds in some towns. An incident in the city of Tallinn (then called Reval) helps to illustrate both the tension between the nobility and the patrician armed societies, and the chivalric skill of the latter.

In the year 1536 the Grand Master of the Livonian Order (a crusading Order linked to the Teutonic Knights of nearby Prussia) arrived in Tallinn to take his vows. During the resulting festivities, an apprentice merchant and a nobleman wanted to perform a joust 
in his honor (Rannu, 1990:67). The nobleman was unhorsed, leading to jeers and an increasing tumult between the assembled burghers and noblemen in the crowd who began to shout at each other. The exasperated Grand Master attempted to subdue the crowd by throwing his hat and the bread from his table, to no avail. The council acted quickly however, ordering the guildhalls and the beer cellars to be locked in order to prevent a disastrous riot. Finally the burgomeister Thomas Fegesack was able to restore order (Rannu, 1990:67).

\section{Societates Armatae}

As mentioned previously, craft guilds were also closely associated with town defense (and offense). Last year I described how the craft guilds of the $13^{\text {th }}$ century in Krakow and Wroclaw established the town militias, influenced the political and military policies of the town, and literally built the walls which fought off the Mongols as well as local seigniorial enemies (Chandler, 2013:117-22,Lepszy 1912:48-53).

In the current issue of the Acta Periodica Duelletorum we have another excellent example of the martial guild or armed society, also mentioned in my previous article, but now fully translated and contextualized by Jürg Gassmann. In his article we can see quite clearly that the craft guilds created a new type of guild organization; the societates armatae. These were armed guilds developed initially to face powerful external enemies (the Holy Roman Emperor during the wars of the Lombard League, and later an important victory over King Enzio of Sardania among notables), and local enemies such as Ghibelline factions in the town and rural nobility outside it.

Bolognese societates armatae followed a pattern of similar armed guilds or societies based around the craft guilds of the artisans, which also appeared in many towns of central and northern Europe around the same time. In addition to the examples from Wroclaw and Krakow there are also many examples further west. In Strasbourg in the mid-13 $3^{\text {th }}$ century, the town militia fought a war against their bishop and nominal overlord, Walter von Geroldseck. The war culminated in a battle at Hausburgen in 1265 in which the "fighting bishop" barely escaped with his life after having three horses killed beneath him. In the aftermath seventy-six of his knights were taken to Strasbourg in chains (Delbrück, 1920: 370).

\section{Guilds, sport, and war}

As early as the $12^{\text {th }}$ or $13^{\text {th }}$ century another type of guild began to emerge: the shütrengessellschaften or shooting guild (Tlusty:2011,189,191), which was somewhere between a paramilitary guild and a sporting club (Tlusty). The first of these were archers and crossbowmen's guilds (Tlusty). We have records of these in certain towns of Flanders, notably Bruges and Ghent among other towns in the Low Country (Verbruggen, 1954:153), and in the Swiss Confederation, but it is probable that they existed throughout Europe at this time (Tlusty). There are records of a crossbow shooting guild in Bern in 1375, and in Lausanne in 1378, and in 1406 a gunners' 
company was established in Neuchâtel. This continued to develop through the $15^{\text {th }}$ century. By 1474 Geneva had three separate shooting guilds, of crossbowmen, archers, and harquebusiers (hand-gunners).

Interestingly, in the Swiss, Flemish, and at least some French towns Saint Sebastian was the patron saint of the archers' guild, while the archers had Saint George and the gunners Saint Barbara, but this was not necessarily the same everywhere. Shooting societies probably played a role in the town defense (Verbruggen,1954:182, Jacquet:2013), but we know that they also had another important benefit to diplomacy but more on that a bit later.

Prizes for shooting contests were not trivial. For example, the shooting contest in Augsburg in 1470 distributed over 900 gulden in prizes to 466 shooters, and another 57 gulden to the winners of horse races, stone throws, jumping contests and foot races (Tlusty:2011,195). Entertainment included bowling, fireworks, sweet confections, and imported wine, and prostitutes who also conducted footraces for the amusement of the crowd (Tlusty,195, 203). Specific prizes included swords, daggers, and women's jewelry and clothing. Women participated in the shooting and were frequently listed among the contest-winners in the records (Tlusty,196). In some cases half the prizes awarded were to women. The expense of shooting contests was offset by the profitable sale of tickets: one contest in Prague in 1560 took in 3,229 gulden in ticket sales and only gave out 1,494 gulden in prizes. The Augsburg contest in 1470 made a profit of 1,120 gulden on ticket sales (Tlusty, 196).

The politics of the contests themselves could be so fraught that they not infrequently caused international incidents. For example in 1508, the famous knight Goetz von Berlichingen took up the cause of Hans Singelfinger, a tailor and marksman from Stuttgart, who due to a misunderstanding was paid less than he was owed for winning a contest he won in Cologne, thus damaging his reputation. Goetz von Berlichingen declared a feud on Cologne on his behalf in 1508, then kidnapped two of the cities merchants, and demanded a 3,000 gulden ransom (Tlusty,2011:208). He settled three years later for 1,000 gulden, and released the merchants in 1511 (he paid Singelfinger 300 gulden, thereby restoring his reputation).

\section{The fencing guilds}

Finally, starting in the $15^{\text {th }}$ century, the first fencing guilds and hand-weapons guilds began to appear. Local Flemish fencing guilds were associated with St. Michael. The first fencing guild in the Holy Roman Empire, of course, was the brotherhood of St. Mark, the Marxbrïder, and later in the $16^{\text {th }}$ century a second fencing guild appeared in the records, the federfechter or Freifechter von der Feder zum Greifenfels linked to Saint Vitus. We also have evidence of fencing guilds in Bruges and Ghent in Flanders, and the Liechtenauer society itself is described in the terms also used for a guild (Gesselschaft).

The specific roles these fencing guilds played in late medieval society in general or in the towns specifically are still not entirely clear, but records do show that the medieval town 
was a fairly violent place. Political violence could be particularly severe, and we know of over 210 guild uprisings in forty towns in the Holy Roman Empire alone from the 14th to the $16^{\text {th }}$ century, but there were undoubtedly many more (Johanek, 2001:306/12). This was also the norm in places such as Poland and Bohemia which had several towns under German town charters. In Italy the Guelph-Ghibelline disputes continued from the $13^{\text {th }}$ through the $16^{\text {th }}$ century, routinely breaking out into urban civil wars which were extraordinarily vicious, and similar violence was common throughout Europe at least intermittently.

One of the differences between the towns of northern and central Europe in this period and those of France, England or Italy was that the town authorities quite deliberately made sure their citizens were armed, and this also meant that they carried swords around town with them. We know that certain towns hired fencing masters, such as Peter Scwhwyzer von Bern, who was hired by Baden in 1485 and Basel in 1490, where he was granted a monopoly by the town council in 1492, then appearing again in the records of Bern in 1502 (Jaquet:2013,58-60).

Though there were laws against fighting and even fines for drawing swords (the latter as early as 1379 , we now know from text translated for this article, in Krakow ${ }^{7}$; see appendix) impromptu duels were not unusual. Routine day-to-day life in the larger towns could occasionally be dangerous, and craftsmen were more likely than anyone to get involved in informal duels and swordfights (Tlusty, 2011:160). The fights, however, were often non-lethal, and when people were hurt or killed adherence to customs and unwritten rules of escalation could determine the degree of punishment meted out for such brawls, which ranged widely (Tlusty, 2011:102). One possible reason for the town to hire a fencing master may have been to teach or encourage proper fencing etiquette, especially among the young male craftsmen and journeymen.

The town governments also sponsored fencing tournaments. Some of these took place as part of shooting contests (such as at Zwickau in 1573) (Tlusty, 2011:213), or on holy days and saints' days, but in at least some places, for example Strasbourg and Augsburg, they seem to have been a routine occurrence in the $15^{\text {th }}$ and $16^{\text {th }}$ centuries ${ }^{8}$. There was certainly a reason for burghers to learn to fence, since they carried swords and knew they might have to use them, both in the militia, on duty in the town watch, or out in a pub in the evening after work. Armed citizens, including journeymen, had a certain inherent value to the town. For example, Ann Tlusty describes a violent incident between a Swedish general and the captain of the town guard of Nordlingen in 1633. If not for the opportune intervention of some armed journeymen, the town may have lost its rights or been sacked by the occupying Swedish army; at the very least the captain of the town watch would have been killed. (Tlusty 2011232-234)

\section{Balthasar Behem Codex, page 7}

8 See the excellent article by Jens P. Kleinau here https://talboffer.wordpress.com/2012/04/25/chronicle-of-the-fencing-guilds-in-augsburg/ 


\section{Points of contact}

Urban and guild civil society overlapped in many ways with the armed guilds. The small amount of data that has been collated so far doesn't give us the whole picture but it does illuminate a few specific links. The connections between the constaffler guilds and the societates armatae are obvious, since they were so closely identified with the merchants and craft artisans respectively in terms of the people involved. Both of these types of armed guilds were also of course directly linked to the town's defense and the militia. But the sword was a sidearm and not, typically, a primary battlefield weapon (with the exception of the montante or the zweihander, perhaps). The lance, the pike, the halberd, the crossbow, and the gun were at the forefront of battle and seem (at least so far) to be the focus of most military training. We don't see a lot of direct evidence, at least so far, that these first two types of armed societies practiced fencing as such.

Carnival may be one of the most interesting and surprising links between fencing and the guilds. Sword dancing, a popular form of entertainment during carnival and all the major festivals, included a type of ritual fight or sparring match between two fencers fighting on platforms of interwoven swords, carried by their peers. In much of the artwork depicting this we can clearly see federschwerter. Tlusty noted that fencing masters often did the ritual fighting up on the platforms (Tlusty, 2011:218). Janssen noted that both the shoemaker's journeymen in Frankfurt am Main and the cutlers, and smith's journeymen in Nuremberg danced the sword dance during carnival (Janssen, 1896:23). This was an urban activity closely associated not just with artisans but with journeymen specifically (Tlusty, 2011:217), and it is interesting that we have so many images of it from Nuremberg since Nuremberg was not a guild town - guilds were legally suppressed there by the town council after a failed guild revolt in the late $14^{\text {th }}$ century. In any event, it may be that certain crafts were specifically associated with the sword dance.

It is also clear that the sword dance was linked to the formal art of fencing; as Tlusty noted, sword dances were often held before fechtschuler with their somewhat violent tournaments (Tlusty 2011:218). This implies a link on the one hand between the ritual entertainment and processional activities on carnival and important saints' feast-days and other holy days, with the practice of the Kunst des Fecbten, and specifically with the craft journeymen. To further reinforce this, we have at least one fencing manual, the Cgm 3711 by the Augsburg fencing master Jörg Wilhalm Hutter, produced in 1520, which has numerous plates depicting fencers in elaborate and sometimes grotesque carnival costumes. 
Journeyman sometimes organized fechtschuler as well. For example Jacob Strauss, a Freifechter and furrier journeyman of Speyer, arranged a "freyen fechtschul" at the dantzhauss in Augsburg on 22 March $1545^{9}$.

By the $14^{\text {th }}$ century, when the first shooting societies show up in the records, the towns were involved in perilous regional wars which required diplomacy with other towns. Perhaps the most important role of the scbützenfest, the urban shooting contest, was that it played in diplomacy. The Swiss Confederation held a scbützenfest in Sursee (now part of Lucerne) to help ease tensions after the Zurich war in 1452. Strasbourg used schützrenfest tournaments to form two important treaties with the Swiss Confederation, an alliance with Zurich against Burgundy in 145610 and an alliance with Berne against the Hapsburgs in 1576 and 1588 (Tlusty,2011:206-207). Training was also clearly a very important role as well. The most effective techniques and emerging technological developments for such new weapons as firearms was from the towns (Johanek, 2000:307). Tlusty, for example, noted that rifled barrels were appearing in shooting contests in Augsburg in the early $16^{\text {th }}$ Cenutry, they were considered cheating and were banned (Tlusty, 2011:200).

The increased mobility of journeymen in the late $14^{\text {th }}$ and $15^{\text {th }}$ centuries in central Europe is of particular interest here once again. As a large percentage of the active male population in the towns, journeymen were an important (and, to be cynical about it, more expendable) part of the town militias. We know they played an important role in the shooting competitions (journeymen were specifically mentioned as the shooters in the 1452 schützenfest in Lucerne).

Patricians, too, had recourse to skill at arms, not just on the battlefield or in naval war, where the lance and the arquebus were perhaps more critical, but also in the realm of personal self-defense. Much of the violence faced by a young merchant in his hazardous profession was on an intimate level. Having survived the vagaries of the high seas or the open road, many were laid low by the blade of an angry business associate or customer, incensed over a debt or the price and quality of goods (Dollinger, 1970:182). It made sense, therefore, for patricians to learn to use a sword.

Though we know that the patricians participated in chivalric tournaments and jousts, and we know that they carried swords, I haven't yet seen much solid evidence that the patricians participated in fechtschuler or similar activities in the medieval period. But we have figures such as Paulus Hector Mair who was a member of the Ausgburg government. We can see from an article by Olivier Dupuis in last year's Acta Periodica Duelletorum that on at least one occasion, a member of the patrician constoffler society of

${ }^{9}$ Cod. Pal. 304 in Die Codices Palatini germanici in der Universitätsbibliothek Heidelberg (Cod. Pal. Germ. 304-495), Matthias Miller, Universitätsbibliothek Heidelberg, Otto Harrassowitz Verlag, 2007 - retrieved via the website of Jens P. Kleinau

10 Heinrich August Pierer, Julius Löbe (Hrsg.): Universal-Lexikon der Gegenwart und

Vergangenheit, 4 Edition. Vol 6, Altenburg (1858), p 697 
Strasbourg acted as a judge for a fechtschule (Dupuis,2013:69-70). There is also the trachtenbuch (tractbook) of Matthäus Schwarz, a wealthy accountant for the Fugger family from Augsburg. The book consists of dozens of portraits of Schwarz in his daily life, and in one of the portraits of the author shows him in fencing pose with the type of sword we call today a federschwert, closely associated with the Kunst des Fechtens. This isn't much so far but I think if we continue to look we will find a great deal more.

\section{CONCLUSION}

We are only just beginning to discern a fuller picture of the reality of medieval guilds, but as the picture continues to take shape, it is possible to at least speculate about the role of the armed guilds and armed societies relative to guild and urban life. When the first armed societies that we know of appeared in the 13th century, craft guilds were rising to prominence in the towns in places like lower Saxony, Flanders, Lombardy, Silesia, and Poland (among others). The towns themselves were becoming more assertive.

We can see a few tenuous connections between the various craft and armed guilds. We know that the fencing guilds were linked to the crafts, (furriers, goldsmiths, butchers, shoemakers and cutlers prominently) and that the shooting guilds were at least indirectly linked to the fencing guilds, since, as Professor Anne Tlusty pointed out, fencing tournaments often took place during shooting contests. A really thorough analysis of the history of the armed guilds is beyond the scope of this paper, but it is worth noting here that the armed guilds do appear to be linked to the greater history of the guilds, and have a place in the historiography. For members of the fencing community, it is chiefly here that the craft guilds, merchants' guilds, and other types of guild organizations become relevant.

At this point, as fencers all we can do is look at the emerging data from the academic community on guilds, consider our own sources, and begin to consider how they might be linked. I have hopefully conveyed that the picture we are starting to see is very complex, rich, and stimulating. The jury may still be out on whether guilds were "good" or "bad," but it does seem likely that they played some role in the martial arts of medieval and early modern Europe. The debate over whether guilds were ultimately "good" or "bad" may ultimately be a little like arguing whether, say, cathedrals, or towns themselves were good or bad.

They were complex features of a complex world which had all kinds of effects across a wide range of time, and they deserve a great deal more attention. In the future, as the scholarship on these interesting phenomena develops, it may yield insights on the roles of skilled and unskilled labor in our own era. Thanks to the wealth of records and literature left to us by our ancestors, much of it yet to be translated or even transcribed, we can be sure that there will be much more to come.

By examining the complex organization of these unique social constructs, we can begin to see where they are linked to warfare and violence, which was never far from the daily 
reality of people in this era. We can also begin to see how they sought to solve this most difficult of problems by creating special societies for the development of martial skill. As more data becomes available, and the patterns in which martial skill touched upon the lives of guild members become clearer, we can, perhaps, begin to better understand the lethal secrets of the books they left behind for us.

\section{APPENDIX - GUILD REGULATIONS AND RECORDS}

Excerpts from the Balthasar Behem Codex (very preliminary translation, translated by Jack Gassman and Christian Trosclair, with assistance by Jean Chandler)

\section{Statuta pellificum 1377 und 1585}

\section{Primo}

He who wishes to gain our guild, he shall put 1 pound of pennies in [the] guild. We shall give our guild to no apprentice (knecht) freed by marrying an unpromised woman. He who wished to gain our guild, he must go with the guild master before the town council ("Herren") to win his citizenship.

If a master promotes/sponsors one who does not have the guild, he who does this must give a firdug, the guild half, the city half or the rest to the guild. A master who belongs to the guild shall in the quarter year give a groschen to the desto. That he may bear witness to the city by necessity [a] harness. Who allows himself to or must speak with the elder and constantly makes speeches in praise, should he not do that shall he be fined $1 \mathrm{gr}$. He who comes after the third call shall give half a groschen. He who does not come to the guild when asked, shall give as fine, one groschen. He who does not come to the body as it is carried out of the house, the same shall give $1 \mathrm{gr}$. He who carries a knife (messer) into the guild [hall] be it great or small he shall be fined a groschen, who speaks a bad/evil word in the guild [hall] shall give one gr. Who with scorn* "frewel" [wearing] harness or his assorted weapons enters the guild [hall], be shall give one mark, half to the city. He who sets a new in place of an old, where one notices and finds the same pelt-piece ("formerswergk") one should take and sell it, what is gained from this must be given to the city two pennies and the third the guild. Who walks with scorn ("frewel") from the guild without the masters permission he shall give six groschen.

If it happens that the masters leave their lord or should leave because of their master, be it that he does not come he shall pay the master six groschen as fines, be it by day or by night. He who sells the pelt-piece with full foreknowledge ("samowss") he or the individual who bas become aware and comes from it, the same pelt piece shall be taken from bim and sold, two pennies shall be given to the city and the third to the guild.

Articles written for the elders and the entire Furriers Community of comrades of Cracow (se inuici) concludes... etc. Anno 1585 


\section{On drawn swords or knives 1379}

It is decided with agreement worthy of blessing, of all the elders to hold fast. Here being, he who draws, or has drawn sword or knife, wherever it is drawn, in street or house or hall of the city, shall give half a mark in fines to the city. He who does not pay the fine shall be confined to a tower for eight days and the armament that is drawn shall be taken by the lord, as according to the privileges about which are given.

\section{Of craftsmen and the Monday celebration 1390}

Those craft apprentices or journeymen who celebrate Monday or one of the other Werseltage in the week without just reason, shall pay the city a firdug fine without complaint and the master shall inform master obediently and loyally which be owes to the city. If the master conceals this then he shall be fined the amount of people he has concealed and also those who have been asked to do so.

\section{BIBLIOGRAPHY}

Acta Periodica Duelletorum, Havana Consulting (2013), Matyas Miskolczi, (Editor)

Daniel Jaquet, Olivier Dupuis, Jean Chandler

Acta Periodica Duelletorum, Havana Consulting (2014), Matyas Miskolczi, (Editor) Jürg Gassman

Bucher, B, 1505/ 1889 Balthasar Behem Codex (Die Alten Zunft Und verkehrs ordnungen dr Stadt krakau nach Balthasar Behem's Codex picturatus in der K. K. Jagellonischen Bibliothek, Vienna 1889)

\section{Brissaud, Jean, 1915. A History of French Public Law, Volume 9, Little, Brown and Co.}

Delbrück, H (Walter J Renfroe, translator), H, 1920. History of the Art of War, Volume III. 1st ed. Westport, Conn: Greenwood Press.

Dollinger, P, 1970. The German Hansa, Vol 1.. 2nd Revised edition Edition. Palo Alto: Stanford Univ Pr.

Eltis, D, 1989. Towns and Defense in Later Medieval Germany, Nottingham Medieval Studies v.33, Nottingham: Brepols

Epstein, S.R. (et al), 2008. Guilds, Innovation and the European Economy. 2nd ed. UK: Cambridge University Press.

Epstein, S. R, 1991. Wage Labor and Guilds in Medieval Europe, Chapel Hill: University of North Carolina Press.

Epstein, "Craft guilds in the pre-modern economy: a discussion", 155-174

Firszt, Stanislaw, 1998. Uržbrojenie oddzialow miejskich w sredniowleczu n pryykladzie miast slaskich, Archeoligia Historica Polona, volume 7, Turn: Uniwiersytet Mikolaja Kopernika

Gies, J., 1995. Cathedral, Forge and Waterwheel: Technology and Invention in the Middle Ages. Harper Perennial.

Guilds, Innovation and the European Economy, 1400-1800, a review, Regina Grafe, Journal of Interdisciplinary History, Volume 40, Number 1, (Summer 2009), pp. 78-82 
Johanek et a., 2000. A Comparative Study of Thirty City-State Cultures: An Investigation Conducted by the Copenhagen Polis Centre (Historisk-filosofiske Skrifter 21). Edition. Kongelige Danske Videnskabernes Selskab.

Janssen, J, 1896. History of the German People at the close of the middle ages, Vol II. 1st ed. London: Kegan Paul, Trench, Trubner \& Co.

Kowaleski, M, 2008. Medieval Towns: A Reader (Readings in Medieval Civilizations and Cultures). University of Toronto Press, Higher Education Division

Lepszy, L, 1912. Cracow, the Royal capital of ancient Poland. 1st ed. New York: Frederick A Stokes Company.

Lucassen (et al), J, 2009. Return of the Guilds. 2nd ed. Cambridge: Cambridge University Press.

Menzel, Wolfgang, 1858 (translated 1908). The History of Germany: From the Earliest Period to 1842, Vol 2, Ann Arbor: University of Michigan press.

Ogilvie, S, 2011. Institutions and European Trade: Merchant Guilds 1000-1800. 1st ed. Cambridge: Cambridge University Press.

Ogilvie, S, 1997. State Corporatism and Proto-Industry: The Württemberg Black Forest, 1580-1797 (Cambridge Studies in Population, Economy and Society in Past Time). Cambridge: Cambridge University Press.

Ogilvie S. C. 2004. "Guilds, efficiency, and social capital: evidence from German proto-industry", Economic History Review, 57, 286-333.

Puhle, Matthias, 1994, Die Vitalienbruder: Klaus Stortebecker unde de Seerauber der Hansezeit, (2 ${ }^{\text {nd }}$ ed), Campus Verglag

Rannu, Elena, 1990. The Living Past of Tallinn. 2nd Edition, Tallinn: Perioodica Publishers.

Schildhauer, Johnnes (Katherine Vanovitch, translator), 1988. The Hansa History and Culture, Leipzig: Dorset Press.

Simons, W, 2001. Cities of Ladies, Beguine Communities in the Medieval Low Countries 1200 -1565. 1st ed. USA: University of Philidelphia Press.

Simpson, P., 1900, Der Artushof in Danqig und seine Brudershaften, die Banken, Danzig: T. Bertling.

Swinton Bland, C.C. (Translator), 1958 The Autobiography of Guibert, Abbot of Nogent-sousCoucy, New York: Macmillan

Tlusty, A, 2011. The Martial Ethic in Early Modern Germany. 1st ed. New York: Palgrave MacMillan.

Verbruggen, J.F. ,1954. The Art of W arfare in Western Europe during the Middle Ages from the Eighth century (Warfare in History) (1988 edition). Suffolk, UK, Boydell \& Brew 